\title{
オオタカ(Accipiter gentilis)の生息に配慮したマツ林管理に関する事例研究
}

\author{
末次 優花 ${ }^{1 *}$. 菅井 理恵 $^{2} \cdot$ 日置 佳之 $^{3} \cdot$ 田中 $\quad$ 郎 ${ }^{4} \cdot$ 土居 克夫 ${ }^{4}$ \\ ${ }^{1}$ 鳥取大学大学院連合農学研究科 $\bar{T} 680-8553$ 鳥取県鳥取市湖山町南 4 丁目 101 \\ 2 干 276-0032 千葉県八千代市八千代台東 5-17-4 \\ ${ }^{3}$ 鳥取大学農学部 $\bar{T} 680-8553$ 鳥取県鳥取市湖山町南 4 丁目 101 \\ ${ }^{4} \mathrm{NPO}$ 法人日本野鳥の会鳥取県支部 干 683-0006 米子市車尾 4-7-29
}

\author{
A Case Study on Pine Forest Management Aimed at Habitat Conservation for the Northern \\ Goshawk (Accipiter gentilis) \\ Yuka Suetsugu ${ }^{1 *}$, Rie Sugai ${ }^{2}$, Yoshiyuki Hioki ${ }^{3}$, Ichiro Tanaka $^{4}$ and Katsuo Doi $^{4}$ \\ ${ }^{1}$ The United Graduate School of Agricultural Sciences, Tottori University, 4-101 Koyamacho-Minami,
Tottori, 680-8551, Japan
${ }^{2}$ 5-17-4 Yachiyodai-higashi, Chiba, 276-0032, Japan
${ }^{3}$ Faculty of Agriculture, Tottori University, 4-101 Koyamacho-Minami, Tottori, 680-8551, Japan
${ }^{4}$ Tottori Chapter of Wild Bird Society of Japan, 4-7-29 Kuzumo, Yonago-shi, Tottori, 683-0006, Japan
}

\begin{abstract}
The Northern Goshawk (Accipiter gentilis Linnaeus 1758), a rare raptor, is listed as an near threatened (NT) species on the red lists by the Ministry of Environment of Japan. Many guidelines about how to manage the forest have been suggested for habitat conservation of the Northern Goshawk, and suggested that active forest management is required to maintain appropriate habitat conditions for extended periods. However, there are few cases of actual active management in Japan. The aim of this study is to evaluate the effectiveness of the active forest management implemented in "The Forest of Accipiter gentilis, Daisen, Tottori Prefecture" by comparing the forest structure and avifauna before and after forest management and to suggest an appropriate management plan. A management plan (Management of pine tree density, improvement by cutting of broad-leaved trees that reached the sub-tall tree layer) was suggested based on the first survey by the Tottori Chapter of the Wild Bird Society of Japan and Tottori University in 2003, and this suggestion was implemented by Tottori Prefecture for the five ensuing years. A second survey, conducted after the management, revealed that pine trees with a large diameter at breast height (DBH) and open spaces between the canopy and understory foliage for flying were preferred as nest areas by the Northern Goshawk. In addition, there was a good foraging range around the case study area. The mosaic of farmland and forest of the Satoyama range was utilized by the Northern Goshawk for foraging. Forest management that includes (1) promoting growth of large diameter trees for nesting and (2) securing flight space in the forest was made clear appropriate for both the conservation of Northern Goshawk habitat and timber cultivation.
\end{abstract}

Key Words: Accipiter gentilis, Pine Forest, Forest Management, Habitat Evaluation, Tottori Prefecture

要旨 : オオタカ (Accipiter gentilis Linnaeus 1758) は，環境省が公表しているレッドリスト 2019 に準絶滅危惧として記載されている希 少猛禽類である.これまで，オオタカの生息環境については日本国内及び海外の事例を基に，多数の基準等や生息環境である針葉樹 人工林の管理方法が示されている. 希少猛禽類の保全については生息環境をより良好に保つことが必須であり，そのためには放置型 の管理ではなく, 状況に応じて積極的に管理する必要がある.しかしながら, オオタカの営巣する森林において, 実際に積極的に施 業を実施し, 好ましい生息環境の維持・改善を試みた事例はほとんど見られない. 本研究では「鳥取県立大山オオタカの森」を事例 研究地として，施業前後の人工林の環境を植生と鳥類の 2 側面から比較·評価し，森林管理のあり方について提言した。具体的には, 2003 年度に日本野鳥の会鳥取県支部及び鳥取大学により実施された第 1 回調査の結果に基づき提案された管理（アカマツの間伐及 び亜高木層に達する広葉樹の除伐）が 5 年間施業された後, 2011 年度に第 2 回調査が実施された. その結果, オオタカは, 営巣木

*連絡先 : suetsugu_yk@outlook.com

受付 : 2017 年 11 月 24 日/受理 : 2020 年 6 月 18 日

${ }^{1}$ 現所属: 株式会社地域計画建築研究所大阪事務所 $\overline{7} 541-0042$ 大阪府大阪市中央区今橋 3 丁目 1-7

Present address: Architects, Regional Planners \& Associates, Kyoto, 3-1-7 Imabashi, Chuo-ku, Osaka, Osaka 541-0042, Japan 
としての大径高木が多数存在し, 営巣林として林内に飛翔空間が広がるアカマツ林を選択していた. また, 事例研究地周辺には田畑 や伐開地など多様な環境が広がっており採餌可能域は良好であった。すなわち, 農地と森林がモザイク状に分布した里地里山の景観 がオオタカの営巣及び採餌環境として利用されていた。 (1)営巣木として利用できる大径高木の育成, (2)林内の飛翔空間の確保を目指 寸森林管理は, オオタカの生息地保全と用材林育成の両方にとって適切であることが明らかとなった.

キーワード : オオタカ, アカマツ林, 森林施業, 生息環境評価, 鳥取県

はじめに

オオタカは, 環境省が公表しているレッドリスト 2019 （日本の絶滅のおそれのある野生生物の種のリス 卜）（環境省自然環境局野生生物課「報道発表資料： 環境省レッドリスト2019の公表について」https:// www.env.go.jp/press/106383.html 最終確認 2020 年 3 月 6 日)，および鳥取県が公表しているレッドリスト（鳥 取県生活環境部公園自然課 2012）で「準絶滅危惧」 に記載されている希少猛禽類であり, 里地里山を象 徵する生態系上位種であることから, その絶滅や減 少による生態系への影響が危惧されている（環境省 自然環境局野生生物課 2012)。才オタカは全国の主に 平地から低山帯に生息し（松江ほか 2006）, 行動圈も 広いことから, 人間活動と切り離した形で保護を図っ ていくことは不可能であり, むしろ人間と共存して 行く方策を積極的に構築していく必要がある（環境 庁自然保護局野生生物課 2012）とされている。 また, 環境省は, オオタカの保全が里地里山の環境の保全 に寄与してきた経緯があるなど, オオタカの保全を 含めた里地里山の保全の重要性を述べている（環境 省「オオタカの国内希少野生動植物種解除亡解除後 の対応についての検討」http://www.env.go.jp/nature/ kisho/domestic/otaka.html 最終確認 2020 年 3 月 6 日). 以上から，オオタカの保全は重要である.

これまで，オオタカの営巣環境や採餌環境の特徴, 生息環境である針葉樹人工林の管理方法については, 日本国内及び海外の事例を基に, 『オオタカの生態と 保全』（尾崎・遠藤 2008） など多数の資料において示 されてきた，オオタカは全国的に針葉樹によく営巣 し, 特にアカマツ (Pinus densiflora) に営巣する個体 が多い.アカマツは営巣に適した樹形を形成するこ とが多く，他の針葉樹よりも架巣しやすい（四手井・ 佐野 1973 ; 堀江ほか 2006）とされている. そのため, オオタカの生息環境としてアカマツ林を維持してい くことは重要である.

アカマツ林は二次林や人工林として全国的に分布 している。一方, 2015 年の国産材生産量の樹種別割 合をみると, スギ, ヒノキ, カラマツ, 広葉樹で 90\%を占めるなど（林野庁 2017）, 全国的にみてアカ
マツ生産量の割合は少なく, 間伐, 枝打ちなどの林 業的な施業が実施され, アカマツが木材として収穫 されている地域は少ない。

加えて, オオタカの営巣する森林において積極的 に施業を実施し，好ましい環境の維持改善を試みた 事例はほとんど見られない。希少猛禽類の保全につ いては生息環境をより良好に保つことが必須であり, そのためには放置型の管理ではなく, 必要に応じて 積極的な施業を実施するなどの森林管理を行う必要 がある，アカマツ人工林は，他の針葉樹人工林と同 様に，人手を入れず放置すると林内の環境が悪化し 大径木の育成が出来ない等の問題が生じる. そのた め, 間伐などの林業的な施業が, オオタカの生息環 境保全と用材林の育成の両面につながる可能性があ る.

そこで本研究では, オオタカを象徵種として希少 な野生動植物が生息できる豊かな自然環境を保全す るために積極的な管理が行われている「鳥取県立大 山オオタカの森」を事例研究地として, 施業前後の 環境の変化を植生と鳥類の 2 側面から把握した. そ して, オオタカの生息地と用材林という 2 つ側面 からみた森林管理のあり方について提言した.

\section{方 法}

\section{1. 事例研究地}

\section{(1) 歴史的背景}

表 1 に事例研究地をめぐる経緯を時系列的に示す. 鳥取県西部に位置する大山（標高 1,729 m）北麓には, 大山マツの産地として全国的に有名なマツ林が存在 する（近藤 1995）。大山のマツ材は工業原料や梁・桁 といった構造材として優秀であるため広大な面積の アカマツ人工林が造林されてきた. 事例研究地の立 地する西伯郡大山町豊房地域も, かつては草刈場と して地域住民に利用されていた（大山町誌編さん委 員会 1980）が, 戦後にアカマツが植林され, 共有林 として地元の人々が管理してきた（小原 私信 2003）. その後, このアカマツ人工林は 1991 年にゴルフ場開 発のために民間企業によって買収されたが，1995 年 にオオタカの営巣が確認された（私信田中 1995）。鳥 
表 1. 鳥取県立大山オオタカの森年表

Table 1. Chronology of the development of "The Forest of Accipiter gentilis, Daisen, Tottori Prefecture"

\begin{tabular}{|c|c|c|}
\hline year & Event & Breeding status of Accipiter gentilis \\
\hline 1991 & Development plan for a Golf Resort & - \\
\hline 1992 & - & - \\
\hline 1993 & - & - \\
\hline 1994 & $\begin{array}{l}\text { Nesting of Northern Goshawk (Accipiter gentilis) } \\
\text { found in the case study area. }\end{array}$ & $\begin{array}{l}\text { Breeding (Young birds did not leave the nest. Signs of } \\
\text { destruction by human.) }\end{array}$ \\
\hline 1995 & - & Breeding (Four Young emerged, three left the nest) \\
\hline 1996 & - & Breeding (Two Young emerged, two left the nest) \\
\hline 1997 & - & Breeding (Two Young emerged, two left the nest) \\
\hline 1998 & - & Breeding (One Young emerged, one left the nest) \\
\hline 1999 & - & No breeding \\
\hline 2000 & - & No breeding \\
\hline 2001 & $\begin{array}{l}\text { Tottori Prefecture purchased the area for } \\
\text { conservation of Northern Goshawk, and designated it } \\
\text { as "The Forest of Accipiter gentilis, Daisen, Tottori }\end{array}$ & No breeding \\
\hline 2002 & - & No breeding \\
\hline 2003 & $\begin{array}{l}\text { The first field survey was implemented. A forest } \\
\text { management plan was proposed based on the survey } \\
\text { findings. }\end{array}$ & Breeding (Two Young emerged, two left the nest) \\
\hline 2004 & - & Breeding (Two Young emerged, one left the nest) \\
\hline 2005 & - & Breeding (Two Young emerged, one left the nest) \\
\hline 2006 & \multirow{5}{*}{$\begin{array}{l}\text { The proposed forest management was implemented for } \\
\text { five years from } 2006 \text { to } 2010 \text {. } \\
\text { (1) Thinning of the pine forest } \\
\text { (2) Improvement by cutting broad-leaved trees that } \\
\text { has reached to the sub tall tree layer }\end{array}$} & Breeding (One left the nest) \\
\hline 2007 & & No breeding \\
\hline 2008 & & No breeding \\
\hline 2009 & & No breeding \\
\hline 2010 & & Breeding (Two left the nest) \\
\hline 2011 & The second field survey was implemented. & Breeding (The nest was abandoned) \\
\hline
\end{tabular}

取県内における繁殖の確認はごく少ない（鳥取県生 活環境部公園自然課 2012）ことから，オオタカ保全 の重要性を認識していた鳥取県は，県内に繁殖する オオタカの主要営巣地の保全を目的として，2001年 にこのアカマツ人工林を取得し，「鳥取県立大山オオ タカの森」と命名した。 2004 年には「鳥取県立大山 オオタカの森の保全に関する条例」が制定され，「リ ゾート開発から絶滅のおそれのある希少な野生動物 であるオオタカの営巣地を守ることを目的として当 該営巣地の存在する森を県が取得した経緯にかんが み, 鳥取県立大山オオタカの森を, 希少な野生動植 物が生息することのできる豊かな自然環境を貴重な 財産として将来に継承し, 環境立県を目指寸象徵と して，県及び県民が一体となって保全する」ことが 決定された（鳥取県「鳥取県立大山オオタカの森の 保全に関する条例」http://wwwl.g-reiki.net/tottori/reiki_ honbun/k500RG00001251.html 最終確認 2020 年 3 月 6 日). 寸なわち,「鳥取県立大山オオタカの森（以下， 事例研究地)」は，オオタカの生息地としてアカマツ 林を管理・保全することを通して，生物多様性が豊 かな森林を目指して設立されたといえる。

鳥取県は, 事例研究地をオオタカの主要営巣林と して保全・管理するために，2003 年度に日本野鳥の 会鳥取県支部及び鳥取大学に委託して第 1 回調査を 実施した。調查結果とそれに基づく森林管理に関す る提言をふまえ，鳥取県は 2006 年から 2010 年にかけ て施業（アカマツの間伐及び亜高木層に達する広葉 樹の除伐）を実施した。 その後，施業後の状況を把 握するために，2011 年度に第 2 回調查を実施した．

\section{（2）立地条件}

図 1 に事例研究地の位置を示寸。事例研究地は 104.5 ha のアカマツ人工林である. 大山北麓に位置し, 標高は $300 \mathrm{~m} \sim 400 \mathrm{~m}$ である. 新期火砕流の堆積面 である火山灰砂台地上にあり，土壤は表層腐植層が 厚く排水のよい多湿黒ボク土（鳥取県農林部農業指 導課 1974）である. 地形は南東から北西に向かって 約 7\% で傾斜する等斉斜面である.

事例研究地及びその周辺の林内や伐開跡地, 周辺 の防風林などにはアカマツのほかにクロマツ (Pinus thunbergii) もみられるが，主林木のほとんどはアカ マツである。また，事例研究地の潜在自然植生は， シラカシ群集 (Quercetum myrsinaefoliae Miyawaki et Ohba 1965）とされている（宮脇ほか 1979）。 シラカ シ群集は一般に地形が平坦で安定し，しかも土袞条 件，とくに表層土が，カシ林域における他の群集よ りも厚い土地に発達する（宮脇ほか 1979）。しかしな がら，事例研究地でシラカシは確認されず，周辺に 現存植生としてのシラカシ群集はみられないことか ら，この潜在自然植生には疑問も残る.

事例研究地から直線距離で東南に約 $18 \mathrm{~km}$ 離れた 岡山県真庭市蒜山上長田（標高 $430 \mathrm{~m}$ ）にある気象庁 のアメダスデータ (2004 年〜 2009 年月別平均気温) によって求められた温量指数（吉良 1949）は77（冷 温帯）であった。ちなみに，2009年の上長田の年間 の日平均気温は $11.3^{\circ} \mathrm{C}$, 日平均最高気温は $16.7^{\circ} \mathrm{C}$, 日 平均最低気温は $6.5^{\circ} \mathrm{C}$, 年降水量は $2,132 \mathrm{~mm}$, 最大積 雪深は $88 \mathrm{~cm}$ であった。

事例研究地内には，南東方向を流れる阿弥陀川に 


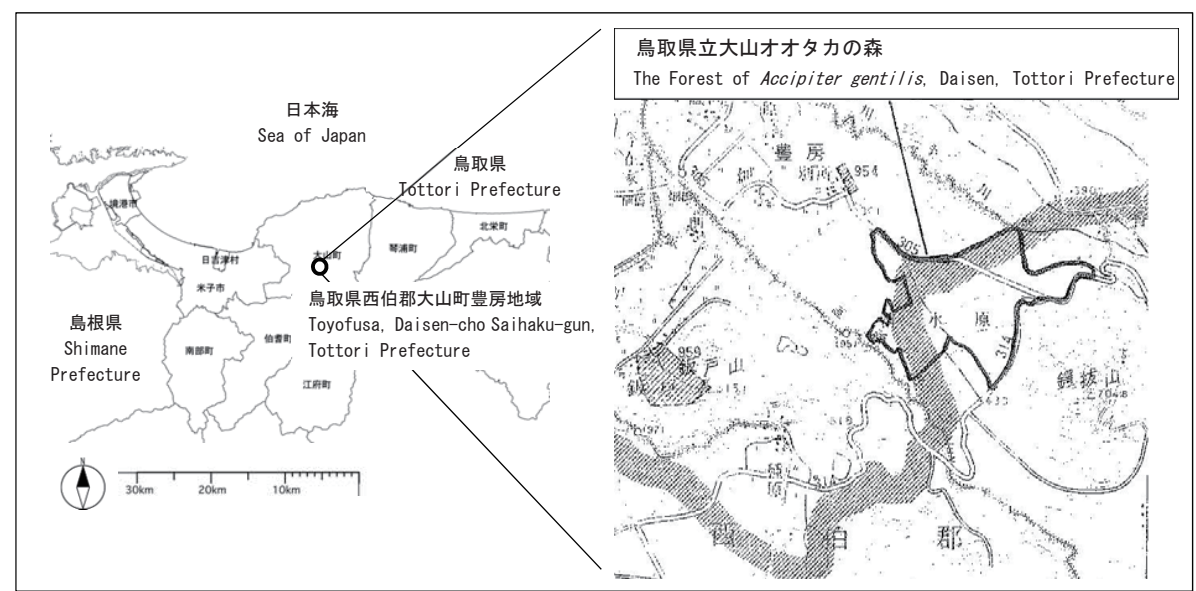

図 1. 事例研究地位置図

Figure 1. Location map of the case study area

続く沢がある、林縁には鳥取県道 315 号線及び 305 号 線などの道路が存在する。周囲は鍔抜山（標高 $705 \mathrm{~m}$ ) や鈑戸山（標高 $515 \mathrm{~m}$ ）などの山々に囲まれ，伐開跡 地や防風林，農耕地などが広がる。

\section{(3) 事例研究地の林齢区分}

図 2 にアカマツの林齢区分および調查地点を示す. 事例研究地のアカマツは, 何回かに分けて植林され たものであるが，植林年等の記録は残されていない (小原私信 2003). そのため, 生育段階の違いがよく 分かる 1974 年の空中写真を用いて, 空中写真の判読 及び現地確認により, アカマツの林齢ごとに $5 つ の$ タイプ $(\mathrm{A} \sim \mathrm{E})$ に区分した林齢区分図を作成した. 2003 年の調査において, A, B タイプからそれぞれ 20 本程度，C，D，Eタイプからはそれぞれ 10 本程度 のアカマツを選抜し, 成長錐（Haglof 社製）を用いて コアサンプルを採取し，樹齢を推定した. A タイプ が最も林齢が高く, 2011 年時点で林齢 66 年生であり, B (51 年生), C (48 年生), D (43 年生), E (40 年生) の順に若齢となっていた. また, B タイプが最も面積 が大きく, A, C, D, Eの順に小さくなっていた. 2003 年以前は A タイプ, 2004 年から 2011 年にかけ てはB タイプでオオタカの営巣が確認された（表 1).

\section{2. 用語の定義}

図 3 に本研究におけるオオタカの生息環境の概念 を示す。ここで述べるオオタカの “生息環境”とは, オオタカの “営巣環境”と“採餌環境”を合わせた 概念である. ある個体が採食・繁殖・育雛に通常利 用する場所である “行動圈”（Burt 1943）と同じ概念 である。

“営巣環境”とは, 営巣地の物理的空間であり, 営
巣木及び古巣周辺で, 営巣に適した林相をもつひと まとまりの区域とされる営巣中心域（環境省自然環 境局野生生物課 2012）と同じ概念である.

“採餌環境”とは，狩りを行う物理的空間及び慨と なる鳥類の生息状況を指し, オオタカの餌動物のた めの良質な生息環境を提供すると共に，オオタカに とって好適な狩り場環境を提供する区域とされる採 食行動域（前橋営林局 1998）と同じ概念である.

\section{3. 調査及び解析方法}

\section{(1) アカマツ人工林における施業}

鳥取県は, 2006 年から 2010 年の 5 年間にかけて, 2003 年の第 1 回調査に基づき提案されたアカマツ人 工林の施業を実施した。施業内容は, (1)アカマツの 間伐（以下，間伐), (2)亜高木層に達する広葉樹の除 伐 (以下, 除伐), (3)マツ枯れ病による枯死木の除伐・ 燻蒸（以下，マツ枯れ対策）である.

2006 年は除伐が重点的に行われ，2007 年から 2010 年は間伐及び除伐が行われた。マツ枯れ対策は 2006 年から 2010 年にかけて実施された。除伐の際には, ヤマザクラ (Prunus serrulata), ウワミズザクラ (Prunus grayana）など野鳥の餌となる果実をつける樹木は残 すよう配慮された。

\section{（2）植生調査}

各林齢タイプの組成と構造を把握するために, 植 生調査を実施した. 調查内容は, (1)毎木調查, (2)植 物社会学的植生調査, (3)林内空間の広がり（立木密 度の算出及び横断面図の作成), とした。期間は, 2003 年 4 月から同年 11 月, 2011 年 4 月から同年 11 月に実施した。 


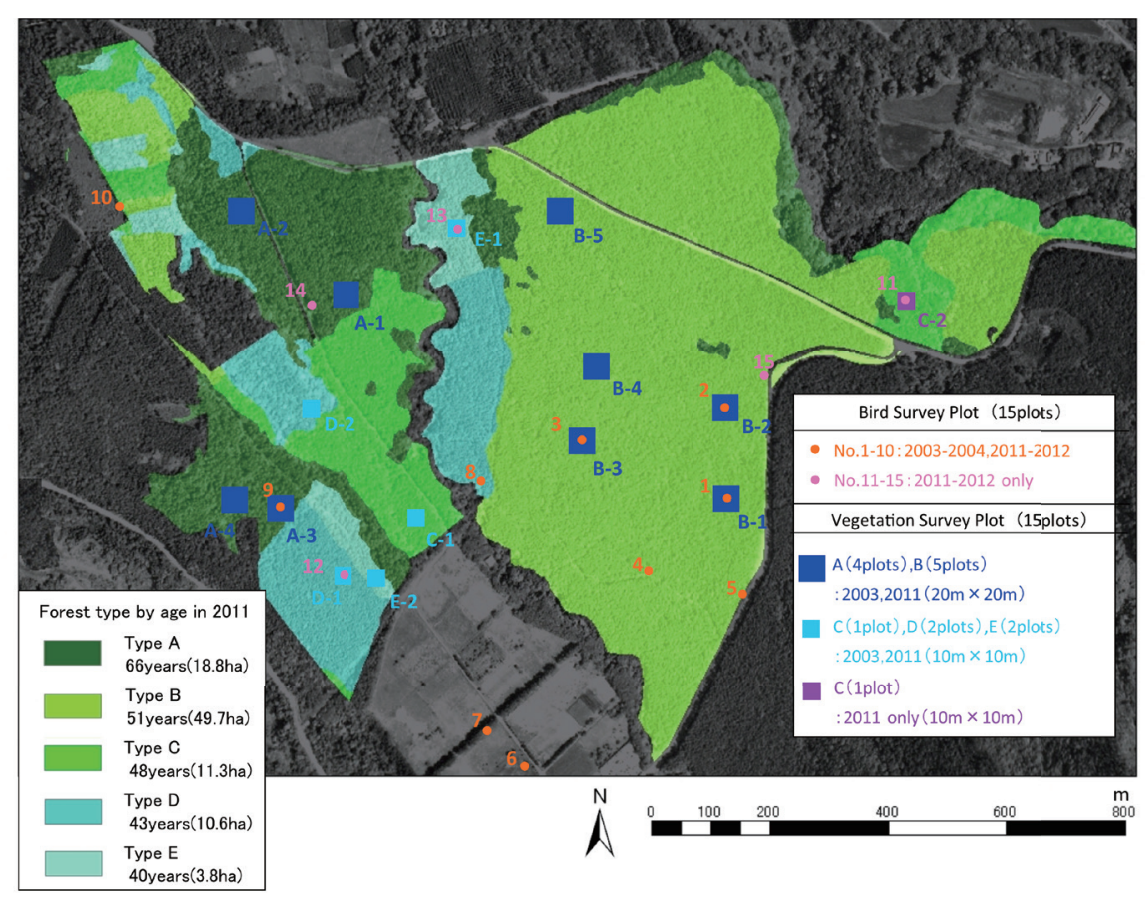

図 2. 事例研究地の 2011 年における林齢区分および調査地点 Figure 2. Forest age in 2011 and locations of the survey plots
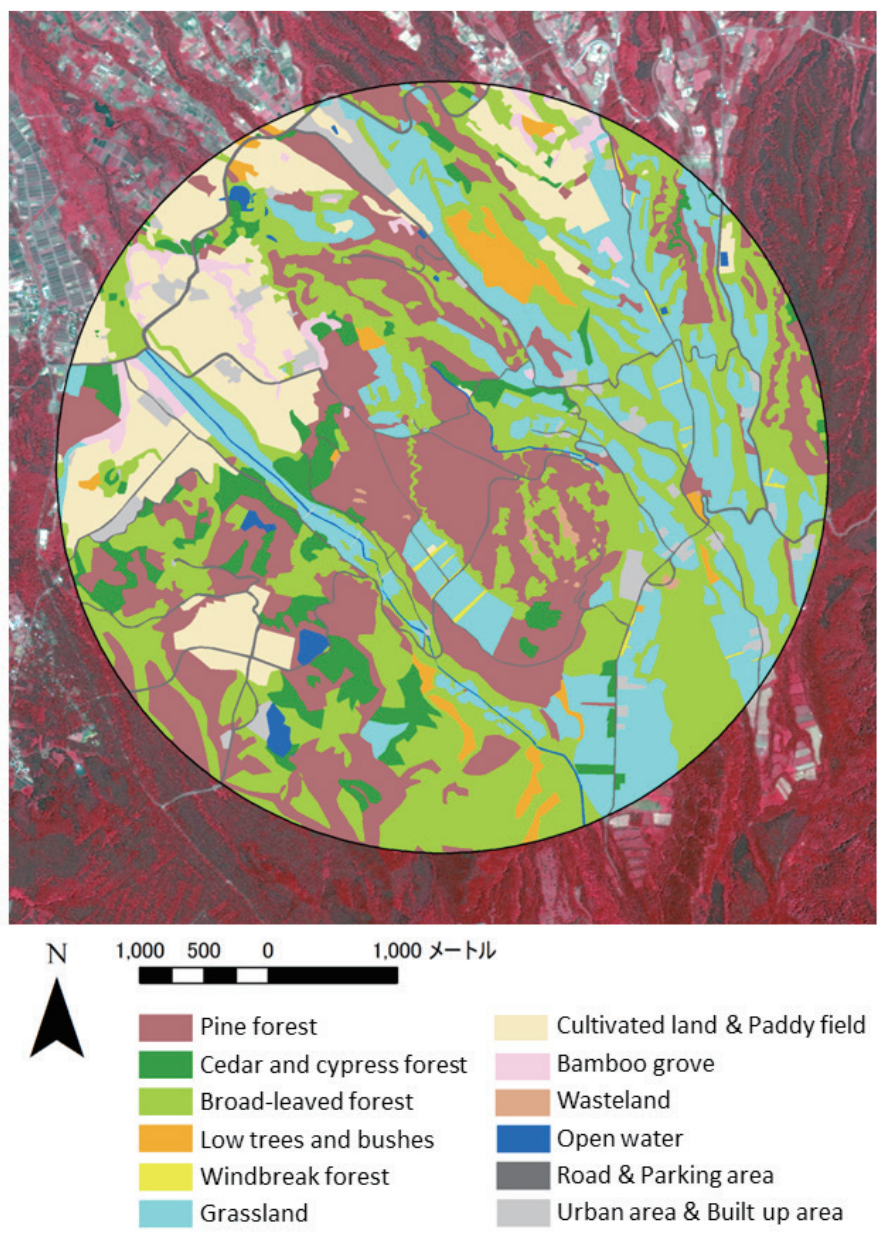

図 4. オオタカ推定行動圈における植生・土地被覆図（2009 年）

Figure 4. A map of the vegetation and land cover of the estimated home range of Accipiter gentilis (2009)

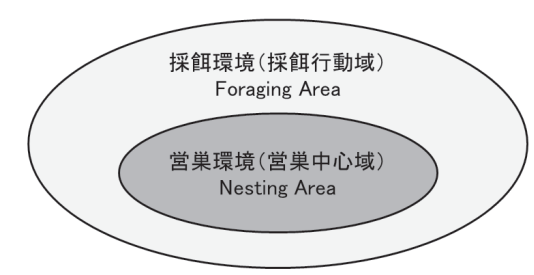

図 3.オオタカの生息環境の概念

igure 3. Schematic habitat structure of Accipiter gentilis

表 2. 植生・土地被覆図の凡例一覧

Table 2. Legend of the vegetation and land cover map

\begin{tabular}{|c|c|c|c|}
\hline \multicolumn{2}{|c|}{ 本事例研究地 凡例 } & \multicolumn{2}{|c|}{ 環境省 $1 / 25000$ 植生図 統一凡例 } \\
\hline 色凡例 & 凡例名 & 統一凡例コード & $\begin{array}{c}\text { 統一凡例名 } \\
\end{array}$ \\
\hline & アカマツ林 & 230100 & アカマツ群落 $(\mathrm{V})$ \\
\hline & アカマツ林 & 420100 & アカマツ群落(VII) \\
\hline & スギ・ヒノキ植林 & 540100 & スギ・ヒノキ・サワラ植林 \\
\hline & 広葉樹林 & 220100 & ブナーミズナラ群落 \\
\hline & 広葉樹林 & 220102 & クリーミズナラ群集 \\
\hline & 広葉樹林 & 300200 & ムクノキーエノキ群落 \\
\hline & 広葉樹林 & 310100 & ハンノキ群落(VI) \\
\hline & 広葉樹林 & 320100 & ヤナギ高木群落(VI) \\
\hline & 広葉樹林 & 410100 & コナラ群落(VII) \\
\hline & 広葉樹林 & 411400 & クサギーアカメガシワ群落 \\
\hline & 低木林 & 440200 & クズ群落 \\
\hline & 低木林 & 460000 & 伐採跡地群落(VII) \\
\hline & 草地 & 250100 & ササ群落(V) \\
\hline & 草地 & 250200 & ススキ群団 (V) \\
\hline & 草地 & 470400 & ヨシクラス \\
\hline & 草地 & 470501 & ツルヨシ群集 \\
\hline & 草地 & 470600 & ヒルムシロクラス \\
\hline & 草地 & 560100 & ゴルフ場·芝地 \\
\hline & 草地 & 560200 & 牧草地 \\
\hline & 耕作地 & 570100 & 路傍·空地雑草群落 \\
\hline & 耕作地 & 570300 & 畑雑草群落 \\
\hline & 耕作地 & 570400 & 水田雑草群落 \\
\hline & 耕作地 & 570500 & 放棄水田雑草群落 \\
\hline & 竹林 & 550000 & 竹林 \\
\hline & 裸地 & 580400 & 造成地 \\
\hline & 裸地 & 580700 & 自然裸地 \\
\hline & 市街地 & 580100 & 市街地 \\
\hline & 市街地 & 580101 & 緑の多い住宅地 \\
\hline & 開放水域 & 580600 & 開放水域 \\
\hline & 道路・駐車場 & 該当なし & \\
\hline & 防風林 & 該当なし & \\
\hline
\end{tabular}




\section{(2) -1 毎木調査}

各林齢タイプに生育するアカマツ及びその他の樹 木の特徵（樹高・胸高直径）を把握するために行った. $20 \mathrm{~m} \times 20 \mathrm{~m}$ の方形プロットを $\mathrm{A}$ タイプに 4 箇所, B タイプに 5 箇所, $10 \mathrm{~m} \times 10 \mathrm{~m}$ の方形プロットを $\mathrm{C} \cdot \mathrm{D} \cdot$ Eタイプにそれぞれ 2 箇所ずつ設置した（図 2). 各 エリアに設置した方形プロットの個数及び大きさは, 佐藤（1971）の標本抽出法を参考に設定した．A・B タイプは，施業前後ともに，樹高が $1.3 \mathrm{~m}$ 以上で胸高 直径が $3.5 \mathrm{~cm}$ 以上の全樹木について胸高直径及び樹 高を測定した。測定した胸高直径から胸高断面積を 算出した. C・D・Eタイプは, 2003 年はアカマツの み測定し， 2011 年はアカマツ以外の樹木が成長し計 測可能となったため, A・B タイプと同様に全樹木に ついて測定した。 なお, $1.3 \mathrm{~m}$ 以下で樹幹が分かれて いる場合は各樹幹を測定した。胸高直径の測定には, 針葉樹は樹幹断面が真円形のため直径割巻尺を，広 葉樹は樹幹断面が不定形のためメジャーを使用し周 囲長の值を計算して直径を求めた。樹高は, 測高竿 とレーザー測距器（TRUPULSE200, レーザーテク） ロジー）を用いて測定した.

各林齢タイプの統計的な差異を把握するために, KRUSKAL WALLIS 検定を行った. いずれも有意水準 は 0.05\%とした。胸高直径, 樹高について，95\%信頼 区間の推定を行い，值のとる区間を求めた。樹高・ 胸高直径の值を用いて一般化線形モデル（以下， GLM）を近似し, 各変数間の関係性を把握した。

\section{(2) -2 植物社会学的植生調査}

事例研究地の植生を把握するために, ブラウン・ ブランケの植物社会学的植生調查法 (Braun-Blanquet 1964）により, 各階層の植被率, 出現種の被度・群度 を記録した。階層区分は，高木層：I 層（15 m 以上), 亜高木層: II 層 $(1.3 \sim 15 \mathrm{~m})$, 低木層: III 層 $(0.5 \sim 1.3$ $\mathrm{m})$, 草本層 : IV 層 $(0.5 \mathrm{~m}$ 未満) の 4 区分とした。調 査地点は, 2003 年は, 毎木調査を行った A・B タイ プに $20 \mathrm{~m} \times 20 \mathrm{~m}$ の方形プロット 9 箇所, $2011 \sim 2012$ 年の調査では新たに C・D・Eタイプの $10 \mathrm{~m} \times 10 \mathrm{~m}$ の方形プロット 6 箇所を加えて 15 箇所とした (図 2).

記録した各階層の植被率から，林分階層多様度 FLD を算出した。 FLD は, 森林において鳥類の種多 様度と正の関係を持つ傾向が知られている群葉高多 様 度 FHD (e.g. MacArthur \& MacArthur 1961 ; Recher 1969）を参考に, 由井（1988）が提唱した指標であり, 以下の式で表される.

$$
\mathrm{FLD}=\left(\sum_{i \leq j=1}^{4} A i A j\right)^{\frac{1}{2}}
$$

FLD は林の階層を高木層, 亜高木層, 低木層, 林 床植生 (本調查では草本層に該当) の四層に分け, 各々 の葉層密度を無, 疎, 中, 密の四段階にランク付けし, 各々に $0,0.33,0.67,1.0$ の仮の重み A を与え, その 林に存在するすべての層同士（階層 $\mathrm{i} \sim \mathrm{j}$ 番目）で $\mathrm{A}$ を掛け合わせて積算し平方根をとったものである。 FLD は林内各層の存在と各層の間の組み合わさり数 の合計，つまりニッチの多さを絶対葉量もある程度 考慮して把握した指数である（由井 1988）. 本研究で は, 各層の植被率を $1 \%$ 単位で記録しているため, よ り的確に葉層密度を反映させるために, 記録した植 被率の值そのものを重み A として計算した.

\section{(2) -3 林内空間の広がり（立木密度の算出と横断面}

\section{図の作成）}

オオタカは営巣林として林内に空間が広がってい る林を選択する傾向があり，その林内の空間を把握 するためには, 立木密度に加えて, 林冠下部に空間 が広がっているかどうかも把握することが重要であ る（Daw et al. 1998 ; DeStefano 1998 ; 鈴木 1999 ; Finn et al. 2002 ; Boal et al. 2006 ; 堀江ほか 2006 ; Squires and Kennedy 2006). そのため, (1)水平方向の空間の広 がり：毎木調査より立木密度の算出, (2)垂直方向の 空閒の広がり：横断面図の作成により林内構造や林 内の空間の広がりを視覚的に把握, 以上 2 点の調査 を行った。

立木密度は, 毎木調査の結果から, 1 ha あたりのア カマツとアカマツ以外の本数を算出した. アカマツ は高木層の, アカマツ以外は亜高木層〜低木層の立 木密度を把握した. 各年の営巣林・非営巣林及び各 林齢タイプの統計的な差異を把握するために, KRUSKAL WALLIS 検定を行った. いずれも有意水準 は $0.05 \%$ とした，立木密度について $95 \%$ 信頼区間の 推定を行い, 值のとる区間を求めた。また, 胸高断 面積・立木密度の平均值を散布図に示し, 各変数間 の関係性を把握した。

横断面図の作成は，各タイプの林内構造は均質性 が高いため, 毎木調査及び植物社会学的植生調查の 調査地点から各タイプ 1 箇所ずつ代表プロットを選 び，方形プロットの中央に $\mathrm{A} ・ \mathrm{~B}$ タイプは $2.5 \mathrm{~m} \times$ $20 \mathrm{~m}, \mathrm{C} ・ \mathrm{D} ・ \mathrm{E}$ タイプは $2.5 \mathrm{~m} \times 10 \mathrm{~m}$ のラインを設け, 
横断面図を作成した。高木層の林冠下部と亜高木層 の林冠上部の間に空間があるか無いかを横断面図か ら確認した.

\section{(3) 生息鳥類調査}

国内におけるオオタカの餌動物は, 鳥が主で（関 東森林管理局編 2008), 小型〜大型の鳥類を主に採餌 し，そのなかでも特に中型鳥類を捕食することがわ かっている（前橋営林局 1998 ; 小俣 1999 ; 尾崎・遠 藤 2008 ; 関東森林管理局 2008). また, 事例研究地の 生物多様性を考察する指標の一つとして, 鳥類の種 多様性の把握は重要だと考えられる。 そこで, 事例 研究地に生息する鳥類の調査を行った.

調査方法は定点観察法とし, 定点から半径 $25 \mathrm{~m}$ の 範囲内に出現した鳥類の種名 - 時間 - 個体数 - 行動 · 出現した階層を記録した。階層は, 上空・上層 $(9 \mathrm{~m}$ 以上 $)$ 中層 $(3 \sim 9 \mathrm{~m})$ ・下層 $(0 \sim 3 \mathrm{~m})$ ・地面の 5 つに区分した。期間は，2003 年 4 月から 2004 年 1 月 に計 11 回, 2011 年 4 月から 2012 年 1 月にかけて計 10 回実施した。

調査地点は，2003～2004 年はアカマツ人工林で A タイプ 1 箇所, $\mathrm{B}$ タイプ 4 箇所, 林縁, 谷, 防風林, 畑, 伐採跡地にそれぞれ 1 箇所の計 10 箇所で実施した. $2011 \sim 2012$ 年は, アカマツ人工林で C タイプ 1 箇所, $\mathrm{D}$ タイプ 1 箇所, $\mathrm{E}$ タイプ 1 箇所, 林縁 2 箇所の計 5 箇所を新たに加え, 計 15 箇所で実施した. アカマツ 人工林の $\mathrm{B}$ タイプ 3 箇所 $(\mathrm{B}-1, \mathrm{~B}-2, \mathrm{~B}-3), \mathrm{A} \cdot \mathrm{C} \cdot \mathrm{D} \cdot$ Eタイプに各々 1 箇所（A-1, C-2, D-1, E-1）の計 7 箇所は植生調査地点と重なっている（図 2).

調査時間帯は，鳥類が良く活動する早朝とし，日 の出から 30 分とした.

また, 関東森林管理局（2008）の好適餌種のサイズ を参考に, 出現した鳥類の大きさを小型・中型・大 型の 3 段階に分類し, 中型鳥類を好適餌種, 小・大 型鳥類をその他として整理した。

解析については, (1)出現個体数のクロス集計表を 用いたカイ二乗検定 (以下, クロス検定), (2) Shannon-Wiener の多様度指数 H' の算出及び母平均の 差の検定, (3) FLD と H’ の GLM, 以上 3 点を行った. (1)については, 各年, 各タイプ, 各調查回の出現個 体数に統計的な差異があるか把握するために, クロ ス検定を行った．有意水準は $0.05 \%$ とした。 (2)につい ては, 各年, 各タイプの鳥類の多様性を把握するた
めに, Shannon-Wiener の多様度指数 H’を算出した.

$$
\mathrm{H}^{\prime}=-\sum_{i=1}^{S} P_{i} \log _{2} P_{i} \quad\left(0 \leqq H^{\prime}\right)
$$

ここで $\mathrm{P}_{\mathrm{i}}$ は一調査区の全種の合計記録数に占める $\mathrm{i}$ 番目の種の記録数の割合である. H’は多様性全体を 表現する指標であり, 数值が高いほど多様性が高い ことを示す. H’は通年と繁殖期について算出した. 繁殖期は, 由井 (1974) を参考に，4月から 8 月の 5 か月間とした. また, 各年の H’ の統計的な差異を把 握するために, 母平均の差の検定（ $\mathrm{t}$ 検定）を行った. 有意水準は $0.05 \%$ とした. (3)については, (2) - 2 植 物社会学的植生調査で算出した各林齢タイプの FLD と H’の值を用いて GLM を近似し, 各変数間の関係 性を把握した。

\section{(4) 営巣木調査}

事例研究地におけるオオタカの営巣木の特徵を知 るために, 営巣木の樹種, 樹高, 胸高直径, 架巣高, 架巣型, その他特徵を記録した. 架巣型は, 『オオタ カの生態と保全』(尾崎·遠藤 2008) に基づき分類した。 調査対象木は, 2010 年および 2011 年の営巣木とした。 左記期間は, 連続して同一の木に営巣していた。 そ れ以外の営巣木は情報を得られなかったため, 調査 対象外とした。

\section{（5）植生・土地被覆図の作成}

事例研究地とその周辺の植生・土地被覆図を作成 した (図 4). 植生・土地被覆図の作成範囲は，才才 タカの採餌環境を把握するために適切なスケールを 設定することが求められる. 環境省により公表され た指針『猛禽類保護の進め方 (改訂版) : 特にイヌワシ, クマタカ, オオタカについて』（環境省自然環境局野 生生物課 2012）では，巣から半径 $3 \mathrm{~km}$ の円を描き, その円とボロノイ領域とが重複した範囲を行動圈と みな寸方法が示されている. 事例研究地では, 営巣 木から半径 $3 \mathrm{~km}$ の円を分割するような近隣の営巣木 は確認されていないため, ボロノイ領域は対象外で ある. そのため, 営巣木調査で特定されたオオタカ の巣の位置から半径 $3 \mathrm{~km}$ の円を行動圈とみなし（以 下, 推定行動圈), 植生 - 土地被覆図の作成範囲とし た (約 $2,827 \mathrm{ha})$.

植生・土地被覆図の作成方法は, 環境省の自然環 境情報 GIS 提供システムにより提供されている 2 万 5 
千分の 1 の植生図を使用することが提案されている が, 現状にあっていない可能性があるため, 航空写真, 現地調査等に基づき，植生図を修正する必要が示唆 されている（環境省自然環境局野生生物課 2012）。事 例研究地を含む作成範囲の 2 万 5 千分の 1 の植生図は, 2009 年に作成されたものであったが，2009 年に撮影 された衛星写真（ALOS 衛星，AVNIR-2 センサ，解像 度 $10 \mathrm{~m}$ ）や現地調査から現状と異なる箇所があった ため，この植生図をそのまま使用することは憚られ た. そのため, 2009 年に撮影された衛星写真を用いて, 2 万 5 千分の 1 の植生図を参考にしながら，推定行動 圈の植生・土地被覆図を作成した。判読にはリモー トセンシング画像処理ソフト（ESRI 社製 ERDAS IMAGINE）を用いた。凡例は，環境省の自然環境情 報 GIS 提供システムの 2 万 5 千分の 1 の植生図に用 いられている統一凡例の環境大区分・中区分の名称 を参考にして，植生および土地被覆ごとに区分した (表 2 参照).
結 果

\section{1.アカマツ人工林における施業}

図 5 にアカマツ人工林の施業実施年度区分図, 表 3 に施業前後のアカマツの平均立木密度および間伐木 の平均胸高直径を示す。間伐は, $10 \mathrm{~m} \times 10 \mathrm{~m}$ の方形 プロットにアカマツが 6 〜 7 本残るように行われた. その結果，間伐後の立木密度は平均 $633 \pm 37.1$ 本/ha となった。林業面からアカマツの立木密度を考える と，アカマツ一般林分密度管理図（安藤 1982）によ れば，立木密度 600 本/ha のアカマツ林では，最大で 樹高 $24 \mathrm{~m}$ 前後，胸高直径 $33 \mathrm{~cm}$ 前後となり，幹材積 $500 \mathrm{~m}^{3} / \mathrm{ha}$ 前後の収量が得られる大径高木の林分にな ると予想される.

また，表 4 に毎木調査の結果を示す．除伐の結果， アカマツ以外の樹木の平均立木密度は A タイプで $2,138 \pm 733.3$ 本 $/$ ha から $1,381 \pm 232.2$ 本 $/$ ha と大幅に 減少した.

マツ枯れ病による枯死木については，松枯れ対策 として，間伐及び除伐の実施時に発見した枯死木は 全て除伐され，燻蒸処理が実施された． 5 年間で計 $111.2 \mathrm{~m}^{3}$ (103 本) が処理された。

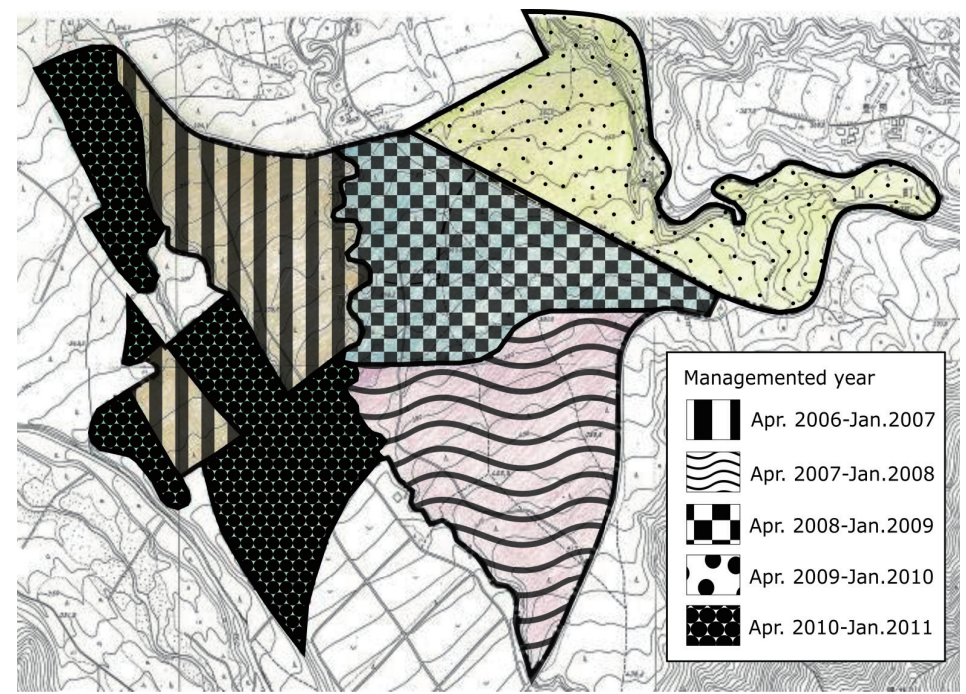

図 5 . 施業実施年度区分図

Figure 5. Forest management history (2006-2010)

表 3. 間伐前後におけるアカマツの立木密度および間伐木の胸高直径

Table 3. The tree stand density and tree diameter at breast height (DBH) of pine trees before and after thinning

\begin{tabular}{ccccc}
\hline \multirow{2}{*}{ Fiscal year } & Forest age type & \multicolumn{2}{c}{ Average stand density (stems/ha) } & $\begin{array}{c}\text { Average DBH of } \\
\text { thinned trees (cm) }\end{array}$ \\
\cline { 3 - 5 } & & Before forest management & After forest management \\
\hline \hline 2006 & $\mathrm{~A} \cdot \mathrm{C} \cdot \mathrm{D}$ & - & - & - \\
\hline 2007 & $\mathrm{~B} \cdot \mathrm{D}$ & 931 & 606 & 17.4 \\
\hline 2008 & $\mathrm{~B} \cdot \mathrm{D} \cdot \mathrm{E}$ & 1,267 & 647 & 21.5 \\
\hline 2009 & $\mathrm{~B} \cdot \mathrm{C}$ & 1,114 & 679 & 29.9 \\
\hline 2010 & $\mathrm{~A} \cdot \mathrm{C} \cdot \mathrm{D} \cdot \mathrm{E}$ & 1,008 & 600 & 21.0 \\
\hline
\end{tabular}

*Pine trees were not thinned in 2006. Only broad-leaved trees were cut for forest improvement. 
表 4. 毎木調查結果

Table 4. Results of the tree census

\begin{tabular}{|c|c|c|c|c|c|c|c|c|c|c|c|c|c|c|c|c|c|c|}
\hline \multirow{3}{*}{$\begin{array}{l}\text { Type of } \\
\text { tree }\end{array}$} & \multirow{3}{*}{$\begin{array}{c}\text { Forest } \\
\text { age } \\
\text { type }\end{array}$} & \multirow{3}{*}{$\begin{array}{c}\text { Number } \\
\text { of } \\
\text { plots }\end{array}$} & \multicolumn{4}{|c|}{ Diameter at Breast Height (DBH) } & \multicolumn{4}{|c|}{ Tree Height } & \multicolumn{4}{|c|}{ Tree Density } & \multicolumn{4}{|c|}{ Tree Basal Area } \\
\hline & & & \multicolumn{2}{|c|}{$\begin{array}{c}\text { Before forest } \\
\text { management }\end{array}$} & \multicolumn{2}{|c|}{$\begin{array}{c}\text { After forest } \\
\text { management }\end{array}$} & \multicolumn{2}{|c|}{$\begin{array}{c}\begin{array}{c}\text { Before forest } \\
\text { management }\end{array} \\
\end{array}$} & \multicolumn{2}{|c|}{$\begin{array}{c}\text { After forest } \\
\text { management }\end{array}$} & \multicolumn{2}{|c|}{$\begin{array}{l}\begin{array}{c}\text { Before forest } \\
\text { managenent }\end{array} \\
\end{array}$} & \multicolumn{2}{|c|}{$\begin{array}{c}\text { After forest } \\
\text { management }\end{array}$} & \multicolumn{2}{|c|}{$\begin{array}{c}\text { Before forest } \\
\text { management }\end{array}$} & \multicolumn{2}{|c|}{$\begin{array}{c}\text { After forest } \\
\text { management }\end{array}$} \\
\hline & & & Ave. $(\mathrm{cm})$ & SD & Ave. $(\mathrm{cm})$ & SD & Ave. (m) & SD & Ave. (m) & SD & $\begin{array}{c}\text { Ave. } \\
\text { (stems/ha) }\end{array}$ & SD & $\begin{array}{c}\text { Ave. } \\
\text { (stems/ha) }\end{array}$ & SD & $\begin{array}{c}\text { Ave. } \\
\left(\mathrm{m}^{2} / \mathrm{ha}\right)\end{array}$ & SD & $\begin{array}{c}\text { Ave. } \\
\left(\mathrm{m}^{2} / \mathrm{ha}\right)\end{array}$ & SD \\
\hline \multirow{5}{*}{ Pine } & $\bar{A}$ & $\overline{4}$ & $\begin{array}{ll}37.0 \\
\end{array}$ & 11.3 & 42.1 & 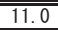 & 20.0 & 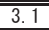 & 21.9 & 2.5 & 36363 & 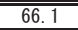 & 344 & $\begin{array}{ll}150.5 \\
\end{array}$ & 4, 271 & 892.1 & (5,306 & 825.9 \\
\hline & $B$ & 5 & 27.0 & 7.8 & 32.2 & 9.0 & 18.4 & 3.4 & 18.7 & 2.9 & 820 & 143.0 & 525 & 135.8 & 5,110 & 334.9 & 4,623 & 552.5 \\
\hline & c & $2^{* 3}$ & 26.9 & 6.2 & 30.0 & 7.7 & 17.2 & 1.5 & 17.6 & 1.0 & 1,300 & 0.0 & 600 & 424.3 & 7,793 & 0.0 & 4,496 & $1,415.6$ \\
\hline & D & 2 & 24.7 & 7.0 & 36.9 & 7.3 & 17.1 & 2.8 & 18.6 & 0.5 & 2,550 & $1,626.3$ & 400 & 141.4 & 13,185 & $9,221.0$ & 4,443 & 178.0 \\
\hline & $E$ & 2 & 19.4 & 5.8 & 30.1 & 6.7 & 12.9 & 2.6 & 17.7 & 3.1 & 1,450 & 212.1 & 500 & 141.4 & 4,680 & 723.6 & 3,724 & 51.6 \\
\hline \multirow{5}{*}{ Others } & $A$ & 4 & 8.3 & 5.5 & 8.5 & 4.5 & 6.9 & 3.6 & 6.7 & 3.3 & 2,138 & 733.3 & 1,381 & 232.2 & 1,679 & 528.2 & $\begin{array}{l}998 \\
\end{array}$ & 200.9 \\
\hline & $B$ & 5 & 5.2 & 1.6 & 6.7 & 2.9 & 6.2 & 1.8 & 7.6 & 3.4 & 1,850 & 439.1 & 1,975 & 437.3 & 433 & 149.1 & 833 & 263.4 \\
\hline & C & $2^{* 33}$ & - & - & 8.1 & 6.0 & - & - & 6.5 & 3.2 & - & - & 2,250 & 777.8 & - & - & 1,798 & 981.2 \\
\hline & $\mathrm{D}$ & 2 & - & - & 7.0 & 3.5 & - & - & 6.7 & 3.5 & - & - & 2,400 & 141.4 & - & - & 1,164 & 461.0 \\
\hline & $E$ & 2 & - & - & 7.1 & 3.0 & - & - & 6.5 & 2.5 & - & - & 1,500 & 0.0 & - & - & 710 & 61.9 \\
\hline
\end{tabular}

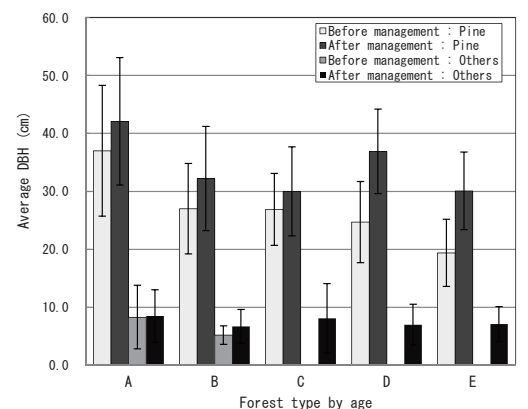

図 6. 胸高直径

Figure 6. Average tree diameter at breast height $(\mathrm{DBH})$ before and after forest management

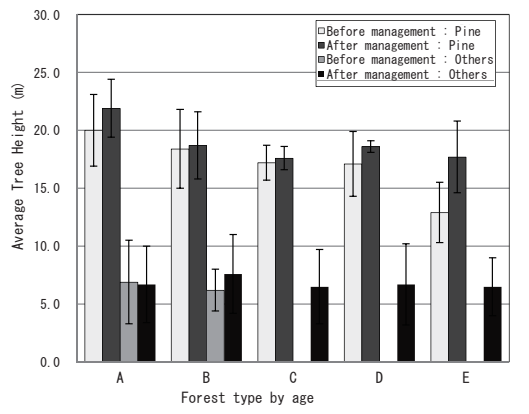

図 7. 樹高

Figure 7. Average tree height before and after forest management

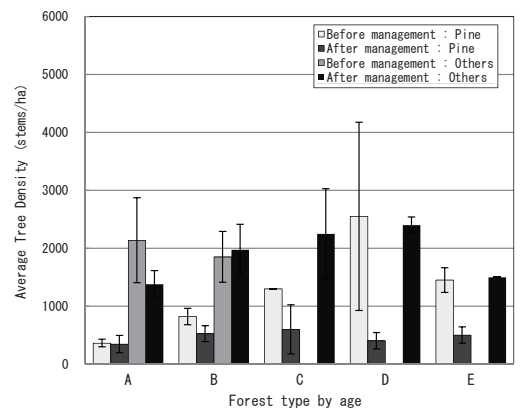

図8, 立木密度

Figure 8. Average stand density before and after forest management

\section{2. 植生}

(1) 毎木調査

(1) -1 調査結果

(1)アカマツ

表 4, 図 6, 図 7, 図 8 に毎木調査の結果を示す.

2003 年におけるアカマツの胸高直径及び樹高の平 均值は, $\mathrm{A}$ タイプで最も大きく, $\mathrm{B}, \mathrm{C}, \mathrm{D}, \mathrm{E}$ タイプ

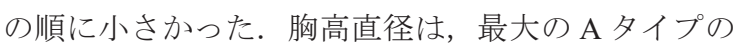
平均值は $37.0 \pm 11.3 \mathrm{~cm}$, 最小の $\mathrm{E}$ タイプの平均值は $19.4 \pm 5.8 \mathrm{~cm}$ であった。樹高は，最大の A タイプの 平均值は $20.0 \pm 3.1 \mathrm{~m}$, 最小の $\mathrm{E}$ タイプの平均值は $12.9 \pm 2.6 \mathrm{~m}$ であった。

2011 年における胸高直径の平均值は, A タイプで 最も大きく, D, B, E, Cタイプの順に小さくなり, 2003 年と傾向が異なった。最大の A タイプの平均值 は $42.1 \pm 11.0 \mathrm{~cm}$, 最小の C タイプの平均值は $30.0 \pm$ $7.7 \mathrm{~cm}$ であり,いずれの林齢タイプも $30.0 \mathrm{~cm}$ を上回っ た。樹高の平均值は, $\mathrm{A}$ タイプで最も大きく, B, D, $\mathrm{E}, \mathrm{C}$ タイプの順に小さかった。 最大の $\mathrm{A}$ タイプの平 均值は $21.9 \pm 2.5 \mathrm{~m}$, 最小の $\mathrm{C}$ タイプの平均值は 17.6 $\pm 1.0 \mathrm{~m}$ であった。

\section{(2)アカマツ以外の樹木}

アカマツ以外の樹木の 2003 年における胸高直径の 平均值は A タイプで $8.3 \pm 5.5 \mathrm{~cm}, \mathrm{~B}$ タイプで $5.2 \pm 1.6$ $\mathrm{cm}$ であった，樹高の平均值は A タイプで $6.9 \pm 3.6 \mathrm{~m}$, $\mathrm{B}$ タイプで $6.2 \pm 1.8 \mathrm{~m}$ であった。胸高直径及び樹高 ともに, A タイプの方が大きかった.

2011 年は全ての林齢タイプでアカマツ以外の樹木 が成長していたため, 全ての林齢タイプで調査を行っ た。 2011 年における胸高直径の平均值は, A タイプ で最も大きく, C, E, D, B タイプの順に小さかった。 最も胸高直径が大きかった A タイプの平均值は $8.5 \pm$ $4.5 \mathrm{~cm}$ であった。樹高の平均值は，B タイプで最も大 きく, $\mathrm{A} ・ \mathrm{D}$ が同值， $\mathrm{C} ・ \mathrm{E}$ が同值でこの順に小さかっ た．最も樹高が大きかった A タイプの平均值は $7.6 \pm$ $3.4 \mathrm{~m}$ であった，胸高直径, 樹高ともに 2003 年よりも 大きかった.

\section{(1) -2 解析結果}

\section{(1)信頼区間}

胸高直径と樹高の信頼区間（95.0\%）を推定した結 果，2003 年は，A タイプの胸高直径は 34.0-40.0 cm, 樹高は 19.2-20.8 m，B タイプはそれぞれ 25.9-28.2 cm, 17.9-19.0 m であった. 2011 年は, A タイプの胸高直 径は 39.1-45.1 cm, 樹高は21.2-22.6 m, B タイプはそ れぞれ 30.5-34.0 cm，18.2-19.3 m であった. 2003 年, 2011 年ともに A タイプの方が B タイプよりも胸高直 径と樹高の信頼区間が大きかった。 2011 年の B タイ プの樹高と胸高直径の信頼区間は, 2003 年 A タイプ 
の值に近づいていた.

\section{(2) KRUSKAL WALLIS 検定}

\section{(2) -1 アカマツ}

2003 年は, 胸高直径, 樹高ともに, 営巣林 (A 夕 イプ）に対して，非営巣林のうち B，D，Eタイプは 差がみられ, C タイプは差がみられなかった $(\mathrm{r}<0.05)$. 非営巣林 (B，C，D，Eタイプ）同士の検定では，E タイプとの組み合わせ (B-E, C-E, D-E タイプ) で 差がみられたが，他の組み合わせ（B-C，B-D，C-D タイプ）で差はみられなかった $(\mathrm{r}<0.05)$.

2011 年は, 胸高直径, 樹高ともに, 営巣林（B夕 イプ）に対して, 非営巣林のうち A タイプは差がみ られ，C，D， Eタイプは差がみられなかった $(\mathrm{r}<0.05)$. 非営巣林 (A，C，D，Eタイプ）同士の検定では，胸 高直径では A-C, A-E タイプの組み合わせで差がみら れたが，その他の組み合わせ（A-D，C-D，C-E，D-E タイプ）で差はみられなかった $(\mathrm{r}<0.05)$ ，樹高は， A タイプとの組み合わせでは全て有意な差がみられた が，それ以外の組み合わせ (C-D, D-E, C-E タイプ) で差はみられなかった $(\mathrm{r}<0.05)$. 胸高直径, 樹高と もに $\mathrm{B}, \mathrm{C}, \mathrm{D}, \mathrm{E}$ タイプの間で差はみられなかった $(\mathrm{r}<0.05)$.

\section{(2) -2 アカマツ以外の樹木}

2003 年は営巣林 (A タイプ) に対して, 非営巣林 (B タイプ）の胸高直径は有意な差がみられたが，樹高 は有意な差がみられなかった（ $\mathrm{r}<0.05, \mathrm{CDE}$ タイプは 未調査.) 一方, 2011 年は営巣林 (B タイプ) に対して, 非営巣林のうち A タイプは胸高直径, 樹高ともに差 がみられたが, C, D, E タイプは差がみられなかった。 また，2011 年非営巣林 (A，C，D，Eタイプ）同士 の検定では, 胸高直径, 樹高ともに有意な差はみら れなかった $(\mathrm{r}<0.05)$.

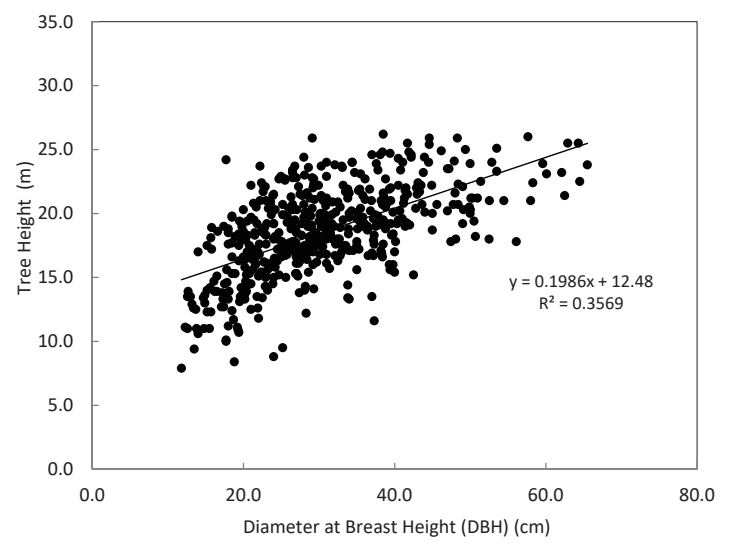

図 9. 胸高直径・樹高の相関図

Figure 9. Correlation diagram of tree diameter and tree height

\section{(3) GLM}

図 9 に 2003 年及び 2011 年のアカマツの樹高と胸高 直径の值を用いた GLM を示す。

樹高と胸高直径は, $\mathrm{y}=0.1986 \mathrm{x}+12.48$ の直線近似式 で $\mathrm{R}^{2}=0.3569 （ \mathrm{r}<0.05 ）$ となり，弱い正の相関がみら れた.

\section{(2) 植物社会学的植生調査}

表 5 に植物社会学的植生調査の結果を示す.階層は, いずれの林齢タイプにおいても，高木層，亜高木層， 低木層及び草本層の 4 つに区分された.

2003 年は, A タイプ, B タイプともに高木層の優 占種はアカマツで, 植被率はそれぞれ 33\%, 56\%で あり，Bタイプの方が高かった。亜高木層は，A タイ プの植被率は $65 \%$, 優占種はエゴノキ, ヒサカキ, ソョゴであった。 B タイプの植被率は $80 \%$, 優占種 はヤマザクラ，クロモジであった。低木層は，A タ イプの植被率は $40 \%$, 優占種はクロモジ，ヒサカキ， ヒメアオキであった。 B タイプの植被率は $48 \%$, 優 占種はハイイヌッゲ, クロモジ, ヒメアオキであった。 草本層は, A タイプの植被率は $27 \%$, 優占種はヤマ ウグイスカグラ他であった。 B タイプの植被率は 14\%，優占種はハイイヌツゲ，クロモジであった。A タイプ, B タイプともに亜高木層の植被率が最も高 かつた。

2011 年は, 高木層の優占種は, 全タイプでアカマ ツであり，植被率は 38 ～55\%であった. 亜高木層の 優占種は A タイプでエゴノキ, コナラ, リョウブ, ウリハダカエデ，A タイプ以外の優占種はヤマザク ラなどのサクラ類等であった，植被率は 48 ～68\%で あった，低木層の優占種は，ネジキ，ヒサカキ，ク マノミズキ, ヤマモミジなど多様な種が共優占して いた. 植被率は $21 \sim 46 \%$ であった. 草本層の優占種 は, ヒメアオキ, クロモジ, ヒサカキ, ハイイヌツ 笛等が共優占していた。植被率は 37 ～74\%であった。 表 5 に林分階層多様度 FLD を算出した結果を示す. A タイプは, 2003 年 $0.99,2011$ 年 1.36 となり, 増加 していた. B タイプは, 2003 年 1.17, 2011 年 1.12 と なり，わずかに減少した。 また，2011 年の C, D, E タイプは $1.01 〜 1.28$ となり, いずれも 2003 年の A タイプよりも大きい值であった. 2003 年と 2011 年の FLDについて母平均の差の検定 (t検定)を行った結果, 有意な差はみられなかった $(\mathrm{P}=.516, \mathrm{r}<0.05)$. 
表 5. 植生調查結果

Table 5. Results of the vegetation survey

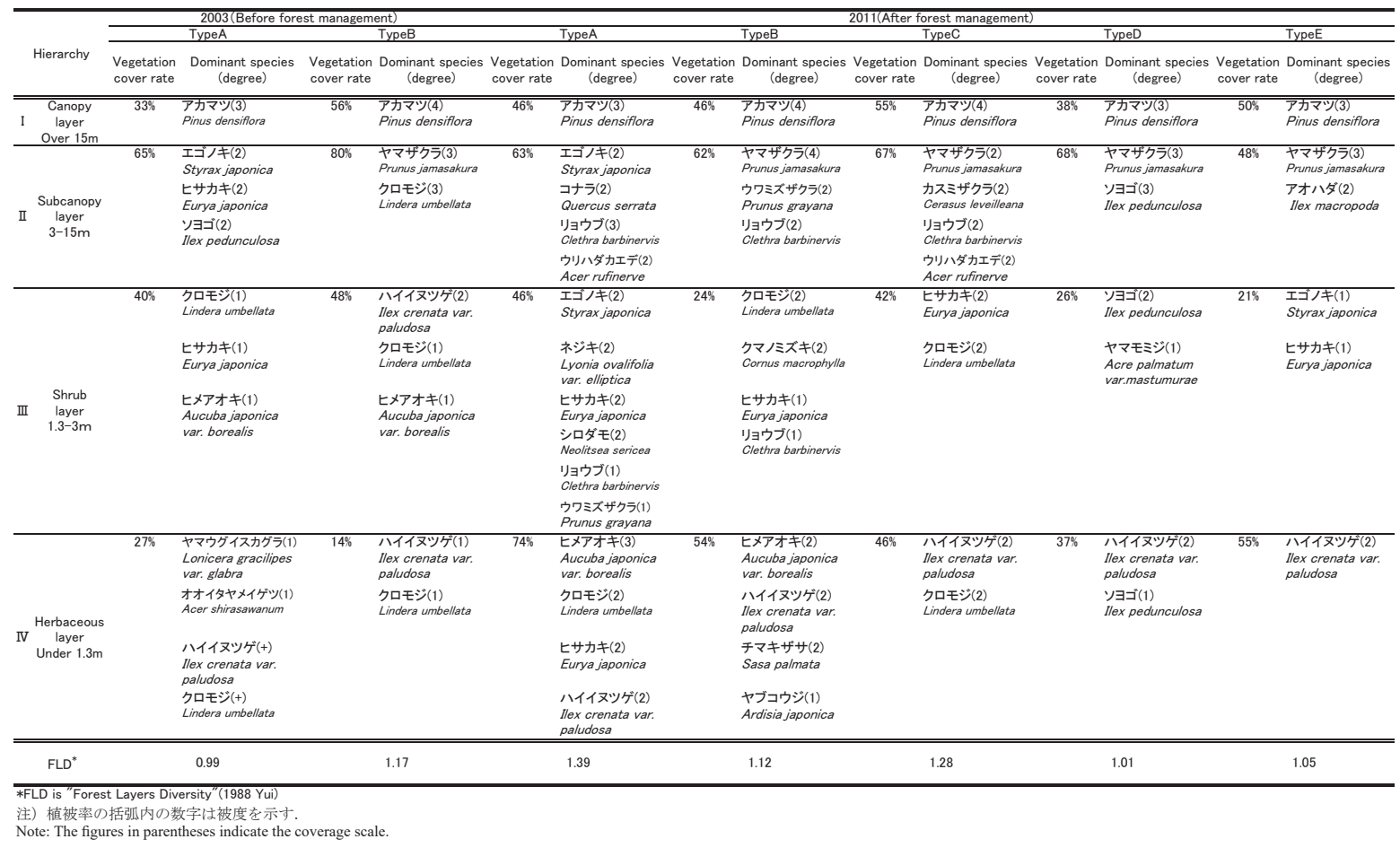

（3）林内空間の広がり

(3) -1 立木密度

\section{(1)調査結果}

立木密度は表 4 及び図 8 のとおりである。アカマ ツの 2003 年における立木密度の平均值は, D タイプ で最も大きく, E, C, B, A タイプの順に小さかった. 最大の D タイプの平均值は $2,550 \pm 1626.3$ 本 $/ \mathrm{ha}$, 最 小の A タイプの平均值は $363 \pm 66.1$ 本/ha であった. 胸高断面積の平均值は, D タイプで最も大きく, C, B, E， A の順に小さかった. 最大の D タイプの平均值は $13,185 \pm 9,221.0 \mathrm{~m}^{2} / \mathrm{ha}$, 最小の $\mathrm{A}$ タイプの平均值は 4,271 $\pm 892.1 \mathrm{~m}^{2} / \mathrm{ha}$ であった. アカマツの 2011 年に おける立木密度の平均值は, $\mathrm{C}$ タイプで最も大きく, B, E， D, A タイプの順に小さかった. 最大の C タイプ の平均值は $600 \pm 424.3$ 本 $/ \mathrm{ha}$, 最小の $\mathrm{A}$ タイプの平 均值は $344 \pm 150.5$ 本/haであり，いずれの林齢タイ プも 1,000 本 /ha を下回った. 胸高断面積の平均值は, $\mathrm{A}$ タイプで最も大きく, B， C, D, E の順に小さくな り, 2003 年と傾向が異なった. 最大の A タイプの平 均值は $5,306 \pm 825.9 \mathrm{~m}^{2} / \mathrm{ha}$, 最小の $\mathrm{E}$ タイプの平均值 は3,724 $\pm 51.6 \mathrm{~m}^{2} / \mathrm{ha}$ であった。

アカマツ以外の樹木の 2003 年における立木密度の 平均值は, A タイプで 2,138 \pm 733.3 本 $/ \mathrm{ha}, \mathrm{B}$ タイプ で $1,850 \pm 439.1$ 本/ha であった。胸高断面積の平均 值は，A タイプで $1,679 \pm 528.2 \mathrm{~m}^{2} / \mathrm{ha}, \mathrm{B}$ タイプで
$433 \pm 149.1 \mathrm{~m}^{2} / \mathrm{ha}$ であった. なお C, D, E タイプは, アカマツ以外の樹木が若齢であったため調查を行っ ていない. アカマツ以外の樹木の 2011 年における立 木密度の平均值は，Dタイプで最も大きく, C, B, E, A タイプの順に小さかった. A タイプは $1,381 \pm$ 232.2 本/ha, B タイプは $1,975 \pm 437.3$ 本/haであった. 胸高断面積の平均值は, C タイプで最も大きく, D, A, B，Eタイプの順に小さかった。最も胸高断面積が大 きかった C タイプの平均值は $1,798 \pm 981.2 \mathrm{~m}^{2} / \mathrm{ha}$, 最 も小さかった $\mathrm{E}$ タイプの平均值は $710 \pm 61.9 \mathrm{~m}^{2} / \mathrm{ha}$ で あつた。

\section{(2)解析結果}

\section{(2) -1 信頼区間 (95.0\%)}

立木密度の信頼区間（95.0\%）を推定した結果， 2003 年営巣林の A タイプは257-468 本/ha, 非営巣林 B, C, D, E タイプの合計值は 706-1974 本/ha となり, 営巣林の方が非営巣林よりも立木密度の信頼区間が 小さかった。 2011 年営巣林の B タイプは356-694 本/ ha，非営巣林 A，C，D，E タイプの合計值は289-586 本/ha となり, 営巣林と非営巣林の信頼区間が一部重 なる結果となった. また, 各年の営巣林（2003 年 A タイプ, 2011 年 B タイプ) と非営巣林 (2003 年 B, C, D, Eタイプ, 2011 年 A, C, D, Eタイプ) の合計值 を用いて立木密度の信頼区間（95.0\%）を推定した結 果，営巣林は 349-556 本/ha，非営巣林は 524-1253 本 


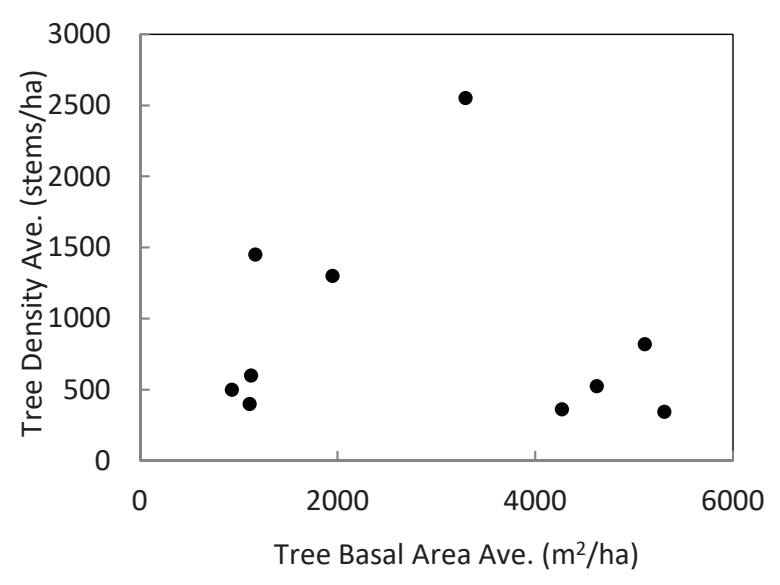

図 10. 胸高断面積・立木密度の平均值の散布図 Figure 10. Correlation diagram of average tree density and average tree basal area

/ha となり，営巣林の方が非営巣林よりも信頼区間が 小さかった。

\section{(2) -2 KRUSKAL WALLIS 検定}

KRUSKAL WALLIS 検定では, アカマツ, アカマツ 以外の立木密度について, 林龃タイプ間に有意な差 があるか検定を行った。

アカマツは, 2003 年営巣林 (A タイプ) と非営巣 林（B， C， D， E タイプ）の組み合わせについては有 意な差がみられたが， 2011 年営巣林（Bタイプ）と 非営巣林（A，C，D，Eタイプ）については有意な差 はみられなかった $(\mathrm{r}<0.05)$.

アカマツ以外の樹木については, 2003 年営巣林（A タイプ）と非営巣林 $(\mathrm{B}, \mathrm{C}, \mathrm{D}, \mathrm{E}$ タイプ), 2011 年 営巣林 (Bタイプ) と非営巣林 $(\mathrm{A}, \mathrm{C}, \mathrm{D}, \mathrm{E}$ タイプ) いずれの組み合わせについても有意な差はみられな かった $(r>0.05)$.

\section{(2) -3 胸高断面積と立木密度の関係}

図 10 に 2003 年と 2011 年のアカマツの胸高断面積 と立木密度の平均值の散布図を示す。事例研究地の アカマツは, (1)胸高直径が小さく立木密度が低いグ ループ, (2)胸高直径が小さく立木密度が高いグルー プ, (3)胸高直径が大きく立木密度が低いグループの 3 つに分かれる. (3)には A, B タイプが含まれ, 大径木 がまばらに生えていると言える.

\section{(3) -2 横断面}

図 11 に横断面図を示す. 2003 年 A, B タイプ, 2011 年 A, B, E タイプは高木層の林冠下部と亜高木 層の林冠上部の間に空間が広がっていることが確認 できた. 2011 年 Cタイプは空間がほとんじ無く, 2011 年 Dタイプは空間が全く無かった.

\section{3. 鳥類}

(1) 調査結果

\section{(1) -1 確認種数}

表 6 に出現鳥類リストを示す. 2003 ～ 2004 年の調 查で確認された鳥類の種数は 61 種であった. このう ち, 環境省レッドデータブック記載種は 2 種, レッ ドデータブックとっとり記載種は 14 種であった. $2011 \sim 2012$ 年の調査で確認された鳥類の種数は 45 種であった。このうち，環境省レッドデータブック 記載種は 3 種, レッドデータブックとっとり記載種 は 8 種であった. 2003〜 2004 年には確認されたが, 2011 ～ 2012 年には確認されなかった種はアオジ，ア マツバメ, オオアカゲラ, コルリ, ツミなど 22 種であっ た. $2011 〜 2012$ 年に新たに確認された種はアカハラ, コシアカツバメ, ハイタカなど 6 種であり, 特定外 来生物指定種であるソウシチョウが確認された.

\section{(1) -2 出現個体数}

表 7 および図 12 に調査地点ごとの出現個体数一覧 を示す. 全地点を総合した出現個体数の平均值は, 好適餌種, その他ともに増加していた. 調査地点ご とにみると, 好適餌種は $\mathrm{B}$ タイプ以外の全ての地点 で増加し，林縁は同数であった，その他の種の合計 值は, 伐採跡地, 谷筋以外の全ての地点で増加して いた. $2011 〜 2012$ 年の調査結果より各林齢タイプの 個体数を比較すると, 好適餌種はCタイプが最も多く, $\mathrm{A}, \mathrm{E}, \mathrm{B}, \mathrm{D}$ タイプの順に多かった.

また, 好適餌種の内訳をみると, 両調査期間とも 上位 3 種はヒヨドリ, キジバト, イカルであり, 好 適餌種合計数に占めるヒヨドリの割合の平均は約 $60 \%$ と 1 位であり，上位 3 種の割合の平均は約 $80 \%$ であった。

\section{(1) -3 季節変化}

図 13 に $2003 \sim 2004$ 年, 図 14 に2 $011 \sim 2012$ 年の 好適餌種における出現個体数の季節変化を示す. 好 適餌種の個体数が最も多かったのは，2003〜 2004 年 では 6 月であり, 次いで1月が多かった. 2011〜 2012 年は 4 月が最も多く, 次いで 5 月が多かった. 両調查期間とも, 通年の好適餌種の合計值が最も多 かったのは林縁であった. 全地点のなかで林縁が最 多であった月は，2003〜2004 年は 5 月〜 6 月，10月 及び 12 月, $2011 \sim 2012$ 年は, 4 月及び 6 月であった.

\section{(1) -4 Shannon-Wiener の多様度指数 H'}

$2003 \sim 2004$ 年における森林内の H’は, 通年では $\mathrm{A}$ タイプ 3.880, $\mathrm{B}$ タイプ 3.748, 繁殖期は $\mathrm{A}$ タイプ 3.737, B タイプ 3.297 となり, A タイプの方が高かっ 

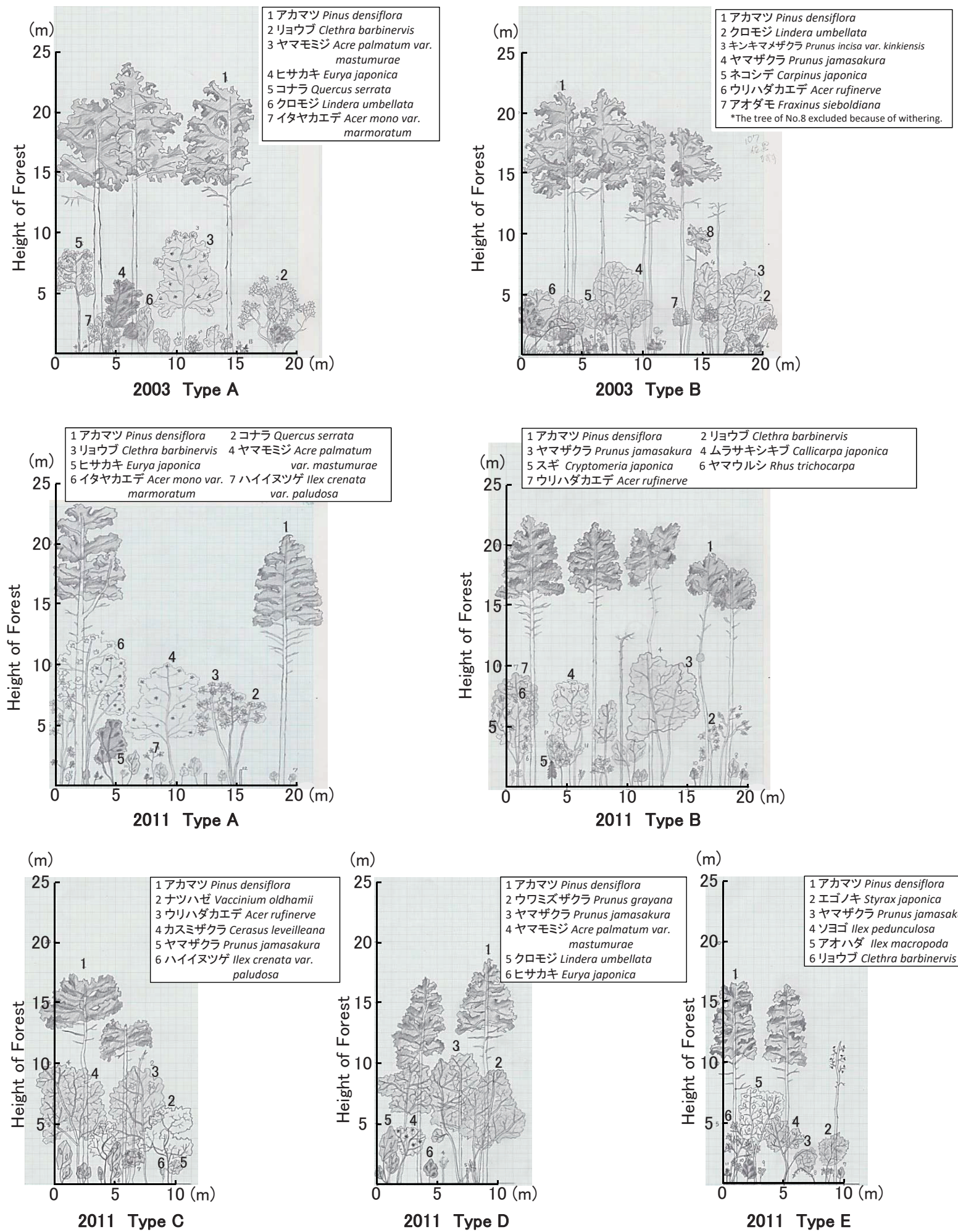

(m)

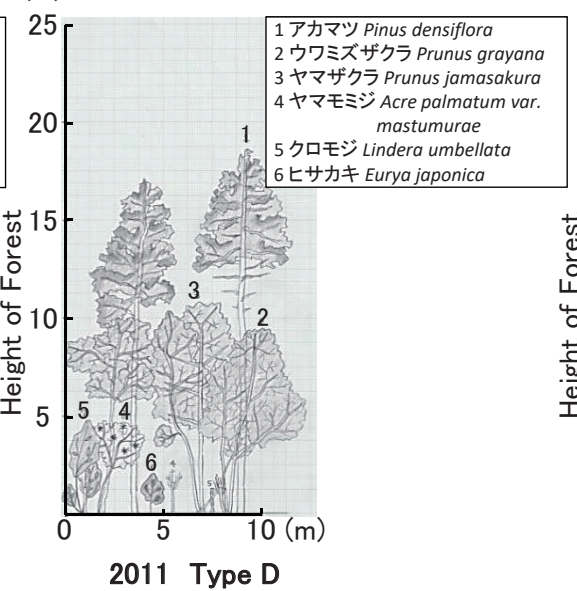

(m)

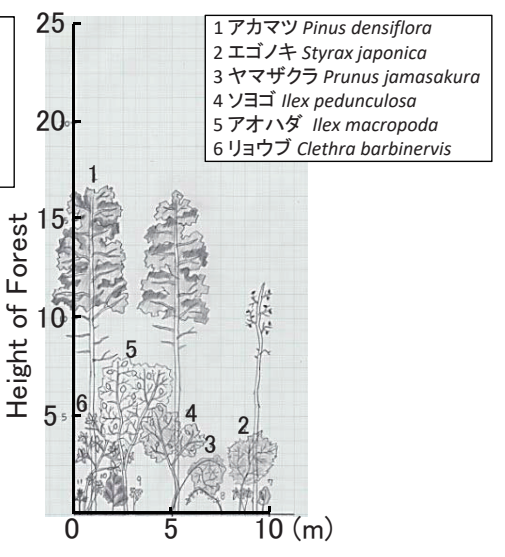

2011 Type E

図 11. 各林齢タイプの横断面図 (上段 : 2003 年 下段 : 2011 年)

Figure 11. Cross-sectional views of each forest type (upper: 2003; lower: 2011) 
表 6 . 出現鳥類リスト

Table 6. The avifauna of the case study area

\begin{tabular}{|c|c|c|c|c|c|c|c|c|}
\hline Japanese Name & Scientific Name & $\begin{array}{l}\text { MEO } \\
\text { RDB } \\
\end{array}$ & $\begin{array}{c}\text { TOTTORI } \\
\text { RDB } \\
\end{array}$ & $\begin{array}{l}\text { Full Length } \\
(\mathrm{cm})\end{array}$ & $\begin{array}{c}\text { Size } \\
(\mathrm{S}, \mathrm{M}, \mathrm{L})\end{array}$ & $\begin{array}{c}\text { Class } \\
\text { (APS }{ }^{* 1}, \text { Others) }\end{array}$ & $\begin{array}{c}\text { Avifauna Apr. } \\
\text { 2003-Jan. } 2004\end{array}$ & $\begin{array}{c}\text { Avifauna Apr. } \\
\text { 2011-Jan. } 2012\end{array}$ \\
\hline アアオゲラ & Picus awokera & & & 29 & $\mathrm{M}$ & APS & $\mathrm{O}$ & $\mathrm{O}$ \\
\hline アオサギ & Ardea cinerea & & & 93 & $\mathrm{~L}$ & Others & 0 & 0 \\
\hline アオジ & Emberiza spodocephala & & & 16 & $\mathrm{~S}$ & Others & $\mathrm{O}$ & \\
\hline アオバト & Treron sieboldii & & NT & 33 & $M$ & APS & $\mathrm{O}$ & $\mathrm{O}$ \\
\hline アカゲラ & Dendrocopos major & & & 23.5 & $M$ & APS & $\mathrm{O}$ & $\mathrm{O}$ \\
\hline アカハラ & Turdus chrysolaus & & & 23.5 & $M$ & APS & & $\mathrm{O}$ \\
\hline アトリ & Fringilla montifringilla & & & 16 & $\mathrm{~S}$ & Others & $\mathrm{O}$ & $\mathrm{O}$ \\
\hline アマツバメ & Apus pacificus & & & 20 & $S$ & Others & $\mathrm{O}$ & \\
\hline アリスイ & Jynx torquilla & & & 17.5 & $\mathrm{~S}$ & Others & 0 & \\
\hline イカル & Eophona personata & & & 23 & $M$ & APS & $\mathrm{O}$ & $\mathrm{O}$ \\
\hline イワツバメ & Delichon dasypus & & & 14.5 & $\mathrm{~S}$ & Others & $\mathrm{O}$ & 0 \\
\hline ウグイス & Cettia diphone & & & $14 \sim 15.5$ & $\mathrm{~S}$ & Others & $\mathrm{O}$ & $\mathrm{O}$ \\
\hline ウソ & Pyrrhula pyrrhula & & & 15.5 & $S$ & Others & $\mathrm{O}$ & \\
\hline エナガ & Aegithalos caudatus & & & 13.5 & $S$ & Others & $\mathrm{O}$ & $\mathrm{O}$ \\
\hline オオアカゲラ & Dendrocopos leucotos & & NT & 28 & $M$ & APS & $\mathrm{O}$ & \\
\hline オオタカ & Accipiter gentilis & NT & VU & $50 / 56.5$ & $\mathrm{~L}$ & Exclusion & $\mathrm{O}$ & $\mathrm{O}$ \\
\hline オオルリ & Cyanoptila cyanomelana & & & 16.5 & $S$ & Others & $\mathrm{O}$ & $\mathrm{O}$ \\
\hline カケス & Garrulus glandarius & & & 33 & $M$ & APS & $\mathrm{O}$ & $\mathrm{O}$ \\
\hline カシラダカ & Emberiza rustica & & & 15 & $\mathrm{~S}$ & Others & $\mathrm{O}$ & $\mathrm{O}$ \\
\hline カワラヒワ & Carduelis sinica & & & 14.5 & $\mathrm{~S}$ & Others & $\mathrm{O}$ & $\mathrm{O}$ \\
\hline キジバト & Streptopelia orientalis & & & 33 & $M$ & APS & $\mathrm{O}$ & $\mathrm{O}$ \\
\hline キクイタダキ & Regulus regulus & & NT & 10 & $\mathrm{~S}$ & Others & $\mathrm{O}$ & \\
\hline キビタキ & Ficedula narcissina & & & 13.5 & $\mathrm{~S}$ & Others & $\mathrm{O}$ & $\mathrm{O}$ \\
\hline クロジ & Emberiza variabilis & & NT & 17 & $\mathrm{~S}$ & Others & 0 & \\
\hline クロツグミ & Turdus cardis & & & 21.5 & $M$ & APS & $\mathrm{O}$ & $\mathrm{O}$ \\
\hline コガラ & Parus montanus & & & 12.5 & $\mathrm{~S}$ & Others & $\mathrm{O}$ & $\mathrm{O}$ \\
\hline コゲラ & Dendrocopos kizuki & & & 15 & $S$ & Others & $\mathrm{O}$ & $\mathrm{O}$ \\
\hline コシアカツバメ & Hirundo daurica & & & 18.5 & $\mathrm{~s}$ & Others & & $\mathrm{O}$ \\
\hline ゴジュウカラ & Sitta europaea & & NT & 13.5 & $S$ & Others & $\mathrm{O}$ & 0 \\
\hline コルリ & Luscinia cyane & & NT & 14 & $S$ & Others & $\mathrm{O}$ & \\
\hline サンコウチョウ & Terpsiphone atrocaudata & & NT & $44.5 / 17.5$ & $S$ & Others & & $\mathrm{O}$ \\
\hline サンショウクイ & Pericrocotus divaricatus & VU & NT & 20 & $S$ & Others & $\mathrm{O}$ & 0 \\
\hline シジュウカラ & Parus major & & & 14.5 & $S$ & Others & $\mathrm{O}$ & $\mathrm{O}$ \\
\hline シメ & Coccothraustes coccothraustes & & & 18 & $\mathrm{~S}$ & Others & $\mathrm{O}$ & \\
\hline ジュウイチ & Cuculus fugax & & & 32 & $M$ & APS & 0 & \\
\hline ジョウビタキ & Phoenicurus auroreus & & & 14 & $\mathrm{~S}$ & Others & $\mathrm{O}$ & \\
\hline シロハラ & Turdus pallidus & & & 24 & $M$ & APS & $\mathrm{O}$ & $\mathrm{O}$ \\
\hline セグロセキレイ & Motacilla grandis & & & 21 & $\mathrm{~S}$ & Others & 0 & \\
\hline セッカ & Cisticola juncidis & & NT & 12.5 & $\mathrm{~S}$ & Others & $\mathrm{O}$ & \\
\hline ソウシチョウ & Leiothrix lutea & & & - & $\mathrm{S}$ & Others & & $\mathrm{O}$ \\
\hline ツグミ & Turdus naumanni & & & 24 & $M$ & APS & $\mathrm{O}$ & $\mathrm{O}$ \\
\hline ツツドリ & Cuculus saturatus & & & 32.5 & $\mathrm{M}$ & APS & $\mathrm{O}$ & $\mathrm{O}$ \\
\hline ツバメ & Hirundo rustica & & & 17 & $\mathrm{~S}$ & Others & 0 & $\mathrm{O}$ \\
\hline ツミ & Accipiter gularis & & NT & $27 / 30$ & $\mathrm{~L}$ & Others & $\mathrm{O}$ & \\
\hline トビ & Milvus migrans & & & $58.5 / 68.5$ & $\mathrm{~L}$ & Others & 0 & $\mathrm{O}$ \\
\hline トラツグミ & Zoothera dauma & & NT & 29.5 & $M$ & APS & 0 & $\mathrm{O}$ \\
\hline ノゴマ & Luscinia calliope & & & 15.5 & $\mathrm{~S}$ & Others & $\mathrm{O}$ & \\
\hline ハイタカ & Accipiter nisus & NT & NT & $31.5 / 39$ & $\mathrm{~L}$ & Others & & $\mathrm{O}$ \\
\hline ハシブトガラス & Corvus macrorhynchos & & & 56.5 & $\mathrm{~L}$ & Others & $\mathrm{O}$ & 0 \\
\hline ハシボソガラス & Corvus corone & & & 50 & $\mathrm{~L}$ & Others & $\mathrm{O}$ & 0 \\
\hline ヒガラ & Parus ater & & & 11 & $\mathrm{~S}$ & Others & $\mathrm{O}$ & $\mathrm{O}$ \\
\hline ヒバリ & Alauda japonica & & & 17 & $\mathrm{~S}$ & Others & $\mathrm{O}$ & $\mathrm{O}$ \\
\hline ヒヨドリ & Ixos amaurotis & & & 27.5 & $M$ & APS & 0 & 0 \\
\hline ビンズイ & Anthus hodgsoni & & & 15.5 & $\mathrm{~S}$ & Others & & 0 \\
\hline ホオジロ & Emberiza cioides & & & 16.5 & $\mathrm{~S}$ & Others & $\mathrm{O}$ & $\mathrm{O}$ \\
\hline ホシガラス & Nucifraga caryocatactes & & $\mathrm{VU}$ & 34.5 & $\mathrm{~L}$ & Others & $\mathrm{O}$ & \\
\hline ホトトギス & Cuculus poliocephalus & & & 27.5 & $M$ & APS & 0 & $\mathrm{O}$ \\
\hline マヒワ & Carduelis spinus & & & 12.5 & $\mathrm{~S}$ & Others & $\mathrm{O}$ & \\
\hline ミサゴ & Pandion haliaetus & & & $54 / 64$ & $\mathrm{~L}$ & Others & 0 & \\
\hline ミソサザイ & Troglodytes troglodytes & & & 10.5 & $S$ & Others & 0 & \\
\hline ミヤマホオジロ & Emberiza elegans & & & 15.5 & $S$ & Others & $\mathrm{O}$ & \\
\hline メジロ & Zosterops japonicus & & & 11.5 & $\mathrm{~S}$ & Others & $\mathrm{O}$ & $\mathrm{O}$ \\
\hline メボソムシクイ & Phylloscopus borealis & & NT & 13 & $S$ & Others & $\mathrm{O}$ & \\
\hline モズ & Lanius bucephalus & & & 20 & $S$ & Others & $\mathrm{O}$ & $\mathrm{O}$ \\
\hline ヤブサメ & Urosphena squameiceps & & & 10.5 & $\mathrm{~s}$ & Others & 0 & 0 \\
\hline ヤマガラ & Parus varius & & & 14 & $S$ & Others & $\mathrm{O}$ & $\mathrm{O}$ \\
\hline \multirow[t]{2}{*}{ ルリビタキ } & Tarsiger cyanurus & & DD & 14 & $\mathrm{~S}$ & Others & $\mathrm{O}$ & \\
\hline & & & & & & Total & 61 & 45 \\
\hline
\end{tabular}

*1 APS: Appropriate play species for Accipiter gentilis 
た. 森林外のプロットでは, 通年は防風林が最も高 く 4.250 となり, 次いで林縁, 畑, 谷筋, 伐採跡地の 順となった。繁殖期は，防風林が最も高く 3.728 とな り, 次いで谷筋, 林縁, 畑, 伐採跡地の順となった。 通年の平均值は, 全プロット 3.638 , 森林 (A, B タ イプ） 3.814, 森林以外 3.568 であった。繁殖期の平均 值は, 全プロット 3.302, 森林 (A, B タイプ) 3.517, 森林以外 3.216 であった。

2011 ～ 2012 年における森林内の H’は，通年では $\mathrm{D}$ タイプが最も高く 4.187 であり, 次いで $\mathrm{C}, \mathrm{B}, \mathrm{E}$, A タイプの順となった. 一方, 繁殖期では, Cタイプ が最も高く 3.774 であり, 次いで A, D, B, Eタイプ の順となった。 森林外のプロットでは, 通年は防風 林が最も高く 3.846 であり, 次いで谷筋, 林縁, 伐採 跡地, 畑の順となった。繁殖期も防風林が最も高く 3.495 であったが, 次いで伐採跡地, 谷筋, 林縁, 畑 の順となり, 通年と傾向が異なった. H’ の平均值は, 2003 ～ 2004 年と同じプロット（C，D，Eタイプを除 く）では, 通年は全体 3.544, 森林 (A, B タイプ) 3.532, 森林以外 3.550 となり, $2003 \sim 2004$ 年よりも小さかっ た. 繁殖期は全体 3.437 , 森林 (A, B タイプ) 3.609 であり，2003〜 2004 年よりも大きかった. $2011 〜$ 2012 年に調查した全地点の平均値は, 通年は全体 3.623 , 森林 (全林齢タイプ) 3.696, 繁殖期は全体 3.484, 森林のみ 3.600 , 森林以外 3.368 となった。

\section{(2) 解析結果}

\section{(2) -1 出現個体数（クロス検定）}

$2003 \sim 2004$ 年, 2011 ～ 2012 年の好適餌種とその 他で出現個体数に有意な差があるかタイプ別 $\left(\mathrm{x}^{2}=0.003, \mathrm{r}>0.05\right)$ と調查回別 $\left(\mathrm{x}^{2}=1.380, \mathrm{r}>0.05\right)$ に クロス検定を行ったが，有意な差はみられなかった。

各年の調査地点ごとに, 好適餌種とその他で出現 個体数に有意な差があるかクロス検定を行ったとこ 万, $2003 \sim 2004$ 年 $\left(\mathrm{x}^{2}=63.328, \mathrm{r}<0.05\right), 2011 \sim$ 2012 年 $\left(x^{2}=28.263, r<0.05\right)$ ともに有意な差がみられ た. $2003 \sim 2004$ 年は，好適餌種の割合が 30\%以上と 多かったのが A タイプ, B タイプ, 林縁であり, そ の他のタイプは好適餌種の割合が $29 \%$ 以下と少な かった. 特に畑, 谷筋はその他の割合が $85 \sim 86 \%$ と 高く, 好適餌種の割合は少なかった. 畑はカワラヒ ワやヒバリなど, 谷筋はアトリやマヒワなどの小型 鳥類の出現個体数が多かったことが理由だと考えら れる. $2011 〜 2012$ 年は，好適餌種の出現割合が 30\% 以上と多かったのが $\mathrm{A}$ タイプ, 伐採跡地, 谷筋であり,
ヒヨドリの出現個体数が多かった. その他のタイプ は好適餌種の割合が 22〜29\%と同程度に少なかった (表 7, 図 12).

\section{(2) -2 季節変化}

調查回ごとの好適餌種とその他の出現個体数に有 意な差があるかクロス検定を行ったところ，2003〜 2004 年は有意な差がみられなかった $\left(x^{2}=8.246\right.$, r $>0.05)$ が, $2011 \sim 2012$ 年は有意な差がみられた $\left(\mathrm{x}^{2}=18.827, \mathrm{r}<0.05\right) .2011 \sim 2012$ 年は, 4 月, 5 月, 8 月, 9 月の調查で好適餌種の割合が $30 \%$ 以上と高く, 最も割合が高かったのは 4 月（繁殖期. 46\%) であっ た.

\section{(2) -3 Shannon-Wiener の多様度指数 H'}

$2003 \sim 2004$ 年と $2011 \sim 2012$ 年の通年の H’につ いて母平均の差の検定（ $\mathrm{t}$ 検定）を行なった結果, 有 意な差はみられなかった（P=0.554， r $<0.05)$ 。また, 繁殖期についても, 有意な差はみられなかった $(\mathrm{P}=0.787, \mathrm{r}<0.05)$.

\section{(2) -4 林分階層多様度 FLD と鳥類の Shannon-Wiener} の多様度指数 H' の関係

2003 ～ 2004 年と $2011 ２ 012$ 年の FLD と鳥類の H’ を用い GLM で関係を見たところ, 通年, 繁殖期のい ずれにおいても， $\mathrm{R}^{2}=0.2$ 以下であり，相関はほとん どみられなかった。

\section{4. 営巣木}

2010 年及び 2011 年に営巣が確認された営巣木はア カマツで, 樹高 $16.2 \mathrm{~m}$, 胸高直径 $43.5 \mathrm{~cm}$, 架巣高 $13.2 \mathrm{~m}$ であった。架巣型は樹幹型であった。

表 8 に事例研究地とオオタカの営巣に関する先行 研究について, 営巣木, 営巣林の特徵 (胸高直径, 樹高等) を比較した結果を示す。これをみると, 2011 年の営巣木の胸高直径は, 先行研究の営巣木と同様 に大きく, 営巣林のアカマツの胸高直径平均值も大 きかった。 また, 営巣林のアカマツの立木密度平均 值は, 先行研究と同様に小さかった.

\section{5. 植生・土地被覆図}

図 4 にオオタカの推定行動圈における植生・土地 被覆図, 表 9 にオオタカの推定行動圈における植生・ 土地被覆図の面積割合を示寸。森林の面積（括弧内 は全体に対する割合）は, アカマッ林 679.74 ha $(24.04 \%)$, スギ・ヒノキ植林 159.84 ha $(5.65 \%)$, 広 葉樹林 852.01 ha (30.13\%) であり, 合計で 1691.59 ha (59.82\%) であった．森林は一箇所に固まることなく, 
表 7. 出現個体数一覧（通年）

Table 7. Total number of bird (year-round)

\begin{tabular}{|c|c|c|c|c|c|c|c|c|c|c|c|c|}
\hline \multirow{4}{*}{ Plot } & \multicolumn{12}{|c|}{ Total number by confilmed in a year } \\
\hline & \multicolumn{3}{|c|}{ year:2003-2004(a) } & \multicolumn{5}{|c|}{ year:2011-2012(b) } & \multicolumn{4}{|c|}{ Difference $(b-a)$} \\
\hline & \multirow{2}{*}{ Others } & \multirow{2}{*}{ APS $^{* 1}$} & $\mathrm{H}^{* 2}$ & $\mathrm{H}^{* 2}$ & \multirow{2}{*}{ Others } & \multirow{2}{*}{ APS $^{* 1}$} & \multirow{2}{*}{$\begin{array}{l}\mathrm{H}^{* 2} \\
\text { Total }\end{array}$} & \multirow{2}{*}{$\begin{array}{c}\mathrm{H}^{* 2} \\
\begin{array}{c}\text { Breeding } \\
\text { season }\end{array} \\
\end{array}$} & \multirow{2}{*}{ Others } & \multirow{2}{*}{ APS $^{* 1}$} & \multirow{2}{*}{$\begin{array}{c}\mathrm{H}^{* 2} \\
\text { Total }\end{array}$} & \multirow{2}{*}{$\begin{array}{c}\mathrm{H}^{* 2} \\
\begin{array}{c}\text { Breeding } \\
\text { season }\end{array} \\
\end{array}$} \\
\hline & & & Total & $\begin{array}{c}\text { Breeding } \\
\text { season }\end{array}$ & & & & & & & & \\
\hline Type A & 62 & 39 & 3.880 & 3.737 & 87 & 54 & 3.300 & 3.742 & 25 & 15 & -0.580 & 0.005 \\
\hline Type B & 74 & 61 & 3.748 & 3.297 & 88 & 30 & 3.763 & 3.476 & 14 & -30 & 0.015 & 0.179 \\
\hline Type C & - & & - & - & 92 & 56 & 3.925 & 3.774 & - & - & - & - \\
\hline Type D & - & & - & - & 47 & 29 & 4.187 & 3.702 & - & - & - & - \\
\hline Type E & - & & - & - & 137 & 48 & 3.304 & 3.305 & - & - & - & - \\
\hline Cutover area & 163 & 59 & 2.829 & 2.537 & 63 & 68 & 3.443 & 3.428 & -100 & 9 & 0.614 & 0.891 \\
\hline Windbreak forest & 80 & 28 & 4.250 & 3.728 & 98 & 36 & 3.846 & 3.495 & 18 & 8 & -0.404 & -0.233 \\
\hline Cultivated land & 89 & 15 & 3.537 & 2.834 & 261 & 34 & 3.173 & 3.163 & 172 & 19 & -0.364 & 0.329 \\
\hline Valley & 205 & 33 & 3.483 & 3.504 & 143 & 69 & 3.683 & 3.408 & -62 & 36 & 0.200 & -0.096 \\
\hline Edge of forest & 112 & 79 & 3.742 & 3.476 & 206 & 79 & 3.603 & 3.345 & 94 & 0 & -0.139 & -0.131 \\
\hline Average:all & 112 & 45 & 3.638 & 3.302 & 122 & 50 & 3.623 & 3.484 & 10 & 5 & -0.015 & 0.182 \\
\hline $\begin{array}{c}\text { Average:all } \\
\text { (avoid TypeC,D,E) }\end{array}$ & 112 & 45 & 3.638 & 3.302 & 135 & 53 & 3.544 & 3.437 & 23 & 8 & -0.094 & 0.135 \\
\hline Average:forest & & & & & 90 & 43 & 3.696 & 3.600 & - & - & - & - \\
\hline $\begin{array}{c}\text { Average.forest } \\
\text { (avoid TypeC,D,E) }\end{array}$ & 68 & 50 & 3.814 & $3.517-$ & 87 & 42 & 3.532 & 3.609 & 19 & -8 & -0.283 & 0.092 \\
\hline Average:others & 130 & 43 & 3.568 & 3.216 & 154 & 57 & 3.550 & 3.368 & 24 & 14 & -0.019 & 0.152 \\
\hline
\end{tabular}

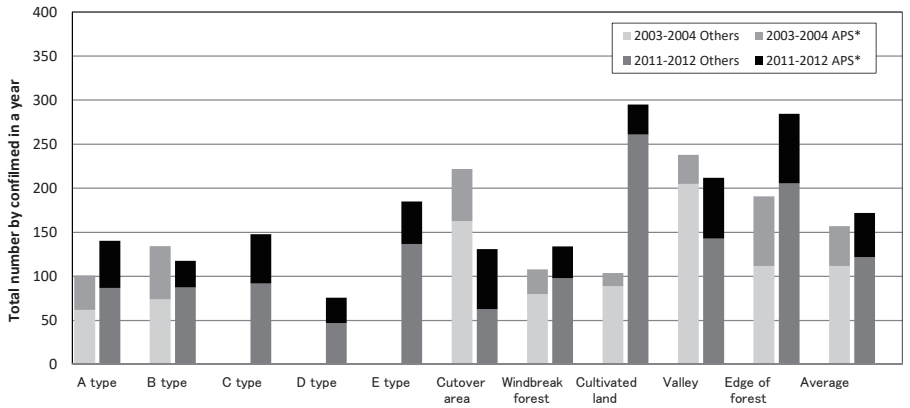

図 12. 出現個体数一覧 (通年)

Figure 12. Total number of bird (year-round)
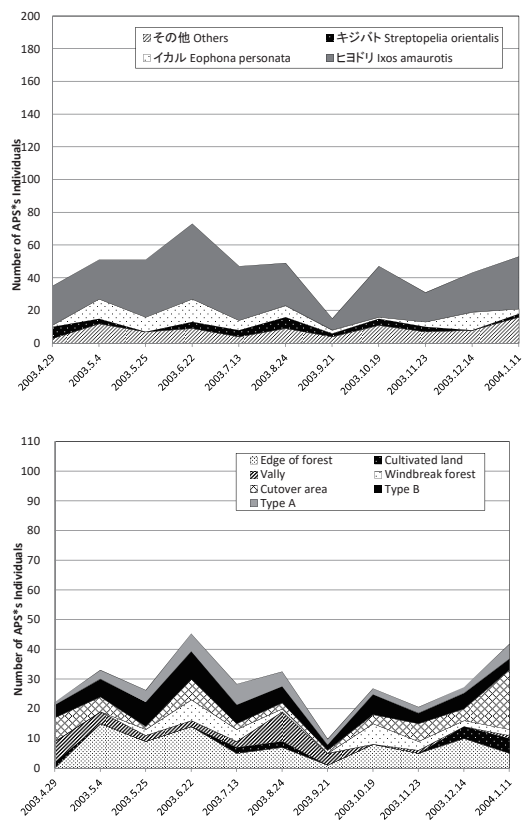

図 13. 季節変化（2003 年度）（上図：好適餌種別 下図： 調查地点別)

Figure 13. Seasonal changes in the bird population / 15 hectares (2003-2004)
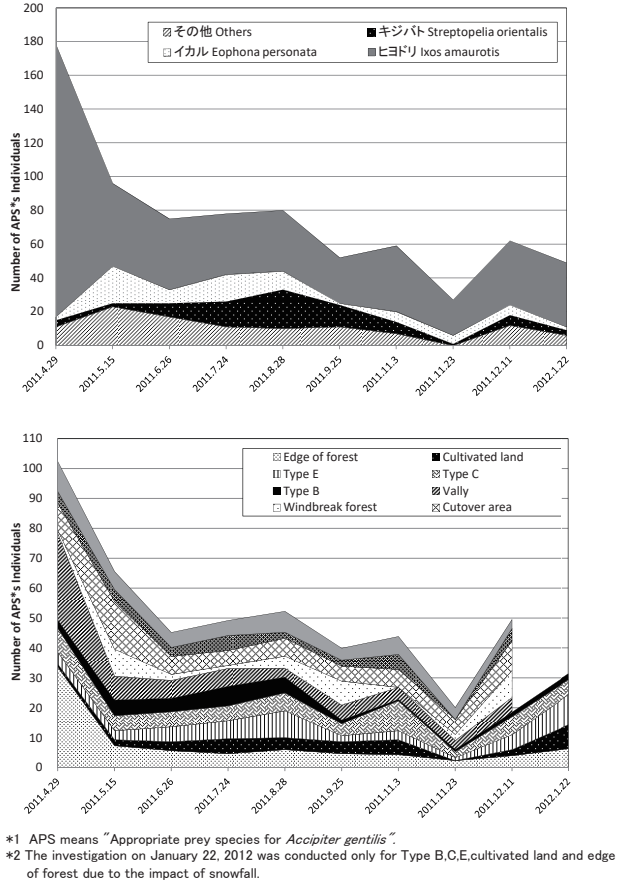

図 14. 季節変化（2011 年度）（上図：好適領種別 下図： 調查地点別)

Figure 14. Seasonal changes in the bird population / 15 hectares (2011-2012) 
全域に分布していた. 草地は 507.38 ha $(17.94 \%)$, 耕 作地（畑，水田）は 332.83 ha (11.77\%) であり，合 計すると全体のおよそ 3 割を占めることがわかった。 低木林は 59.45 ha $(2.10 \%)$, 防風林は 6.83 ha $(0.24 \%)$, 竹林は 46.88 ha (1.66\%) と少ない面積ではあったが, 全域に飛び石状に散らばって分布していた。開放水 面は 25.82 ha $(0.91 \%)$ であり, 南から北西に向かっ て流れる河川のほか，いくつかの池が北西及び南西 に分布していた．裸地は 5.58 ha $(0.20 \%)$ であり，南 東のアカマツ林・広葉樹林内に分布していた。 道路・ 駐車場及び市街地などの人工的な施設については, 道路・駐車場が 74.8 ha（2.65\%） と森林などよりも少 なく全域に粗い網目状に分布しており，市街地は 76.72 ha $(2.71 \%)$ と少なかった.

\section{考 察}

\section{1. 植生}

\section{(1) 営巣林及び営巣木}

オオタカは, 大径高木に営巣する傾向があり（堀 江ほか 2006 ; 内田ほか 2007 ; 尾崎・遠藤 2008 ; 財団 法人道路環境研究所 2008 ; 平井ほか 2008), 樹高より も胸高直径が重視される傾向がある（鈴木 1999 ; 農 林水産技術会議事務局 2003 ; 堀江ほか 2006)。事例研 究地におけるアカマツの胸高直径および樹高の KRUSKAL WALLIS 検定により，2003 年は営巣林（A タイプ）に対してほとんどの林齢タイプで有意な差 がみられた。 そのため, 事例研究地でも大径高木の 多い林分が営巣林として選択されたと考えられる。 加えて, 事例研究地の営宩木と先行研究を比較する と胸高直径が太い（表 8) ことや，事例研究地のアカ マツの樹高と胸高直径は弱い正の相関（図 9）しかな く, 胸高直径が大きければ樹高も比例して高くなる 傾向は小さいことから, 事例研究地の営巣木は胸高 直径が重視され, 営巣林内で相対的にみて大径木が 選択されたと考えられる.

これに対し，2011 年の胸高直径および樹高につい て, KRUSKAL WALLIS 検定により営巣林 (B タイプ) に対して有意な差がみられたのはAタイプのみであ り，その他の非営巣林 $(\mathrm{C}, \mathrm{D}, \mathrm{E}$ タイプ）に有意な 差はみられなかった。 アカマツの胸高直径及び樹高 の信頼区間 $(95.0 \%)$ の推定結果をみると，Bタイプ は2011 年には 2003 年時点で営巣林であった A タイ プと同程度に大きくなっていた，そこで，A，B タイ プにおけるアカマツの胸高直径一樹高相関図（図 15）
において, 現在の営巣木よりも大径高木であれば潜 在的に営巣木として選択される可能性が高いとみな し, 胸高直径・樹高が営巣木よりも大きなアカマツ の 1 ha あたりの本数を算出した. B タイプは, 施業 後に営巣木よりも大きな大径高木が 2003 年は 20 本 / ha であったが, 2011 年は 60 本 /ha と 3 倍に増加して いた. 以上から, 2011 年までに全ての林齢タイプの アカマツが伸長・肥大成長し, 営巣林として選択さ れる可能性のある大径高木林に成長してきたと考え られる. これは，2006〜2010 年に実施された間伐に よる立木密度低下の効果と考えられる.

\section{（2）林内の飛翔空間の広がり}

水平方向の空間の広がりは, 立木密度を用いて把 握した. 2003 年時点で営巣林に選択されていたのは, アカマツの立木密度が最も低い A タイプ (363 本/ha) であり，KRUSKAL WALLIS 検定により，2003 年営巣 林と非営巣林の間には有意な差がみられた。このこ とから, 事例研究地においても, 先行研究 (鈴木 1999 ; 平井ほか 2008 ; 関東森林管理局 2008 ; 財団法 人道路環境研究所 2008）と同様に，立木密度が低い 林分が営巣林として選択されたと考えられる. 加え て, 事例研究地の営巣林の立木密度は, 先行研究と 比べて低かった（表 8）ことから，相対的にみて立木 密度が低い林分を選択したと考えられる. 間伐の結 果, 2011 年には, 全林齢タイプでアカマツの立木密 度が低下した（表 4, 図 8). KRUSKAL WALLIS 検定 により，2011 年の営巣林と非営巣林の間には有意な 差がみられなかったこと，信頼区間（95.0\%）の推定 結果から 2011 年の営巣林と非営巣林の推定区間は重 複がみられたことから，2011 年までには全林齢タイ プが潜在的に営巣林として選択される立木密度に低 下したと考えられる。また, 2003 年・2011年のアカ マツの胸高断面積と立木密度の平均值の散布図（図 10）より，胸高直径が大きなアカマツがまばらに立 ち並んでおり, 水平方向の飛翔空間が広がっている ことが示唆された.

垂直方向の空間の広がりは, 植生調查で作成した 横断面図を用いて把握した. Boal（2005）は，営巣林 は林冠下部と低木層の間に開放空間がある林が選択 されていると述心，他の先行研究（前橋営林局 1998 ; 植田ほか 2006 ; 堀江ほか 2006 ; 関東森林管理局 2008）も，亜高木層が無いか疎で低木層あるいは草本 層と樹冠との間に空間があることが重要だと述べて いる. 事例研究地では, 営巣林として選択された 
表 8. 本研究と他事例の営巣木及び営巣林の比較

Table 8. Comparison of the nesting trees and nesting forests in the study area and in other cases

\begin{tabular}{|c|c|c|c|c|c|c|c|c|c|c|c|c|}
\hline & No. & 1 & 2 & 3 & 4 & 5 & 6 & 7 & 8 & 9 & 10 & 11 \\
\hline \multirow{2}{*}{\multicolumn{2}{|c|}{ References, etc. }} & & the study area & & 1996 & 1998 & 2008 & 2008 & 1999 & 2008 & 2003 & 1999 \\
\hline & & $\begin{array}{c}2003 \\
\text { Nested Forest }\end{array}$ & $\begin{array}{c}2011 \\
\text { Nested Forest }\end{array}$ & $\begin{array}{l}\text { 2010, } 2011 \\
\text { Nesting Tree }\end{array}$ & $\begin{array}{c}\text { EEviroment } \\
\text { Agency, Nature } \\
\text { Conservation } \\
\text { Bureau, Wildife } \\
\end{array}$ & $\begin{array}{c}\text { Maebashi } \\
\text { Forestry } \\
\text { Administration }\end{array}$ & Ozaki-Endo & $\begin{array}{l}\begin{array}{l}\text { Foundation rad } \\
\text { Institut for } \\
\text { Environmental } \\
\text { Studies }\end{array} \\
\end{array}$ & Suzuki & Hirai et al. & $\begin{array}{l}\text { Agriculture, Forestry } \\
\text { and Fisheries } \\
\text { Research Counil } \\
\text { Secretariat }\end{array}$ & Komata \\
\hline \multirow{2}{*}{\multicolumn{2}{|c|}{ Nesting area }} & \multicolumn{3}{|c|}{ Tottori prefecture } & \multirow[b]{2}{*}{-} & \multirow[b]{2}{*}{-} & \multirow[b]{2}{*}{-} & \multirow[t]{2}{*}{ 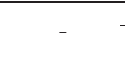 } & \multicolumn{3}{|c|}{ Hokkaido } & ori to Gifu \\
\hline & & & isen-cho Toyofusa & a area & & & & & Tokac & chi plain & Ishikari plain & prefecture \\
\hline \multirow{5}{*}{$\begin{array}{l}\text { Nesting } \\
\text { tree }\end{array}$} & Tree type & & $\begin{array}{c}\text { アカマッ } \\
\text { Pinus densiflora }\end{array}$ & & - & 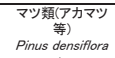 & 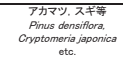 & 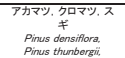 & $\begin{array}{c}\text { カラマ゙ッ } \\
\text { Larix kaempferi }\end{array}$ & $\begin{array}{l}\text { カラマッ⿻, 자ローナマ } \\
\text { M } \\
\text { Larix kaempferi, }\end{array}$ & 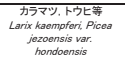 & 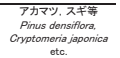 \\
\hline & $\mathrm{DBH}(\mathrm{cm})$ & - & 43.5 & 43.5 & Over 25 & Over 25 & Over 30 & Over 30 & $\begin{array}{l}37.8 \\
( \pm 7.6) \\
\end{array}$ & $\begin{array}{c}38.6 \\
( \pm 7.1) \\
\end{array}$ & $\begin{array}{c}36.8 \\
( \pm 15.0) \\
\end{array}$ & $\begin{array}{c}34 \\
(18.0-60.0) \\
\end{array}$ \\
\hline & Height(m) & - & 16.2 & $\overline{16.2}$ & Over 15 & Over 15 & - & Over 16 & $\begin{array}{c}22.1 \\
( \pm 2.5) \\
\end{array}$ & $\begin{array}{c}25.5 \\
( \pm 3.6) \\
\end{array}$ & $\begin{array}{l}19.4 \\
( \pm 4.6) \\
\end{array}$ & $\begin{array}{c}15.9 \\
(1.0-30.0) \\
\end{array}$ \\
\hline & Nest & - & 13.2 & 13.2 & - & - & - & Over 11 & 11.6 & 12 & - & 11.5 \\
\hline & height( $m)$ & 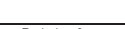 & & & - & - & & Tree height $70 \%$ & $( \pm 3.0)$ & $( \pm 3.5)$ & - & $(7.0-21.0)$ \\
\hline \multirow{4}{*}{$\begin{array}{l}\text { Nesting } \\
\text { forest }\end{array}$} & Forest type & $\begin{array}{l}\text { Red pine forest } \\
\text { (TypeA) }\end{array}$ & $\begin{array}{l}\text { Red pine forest } \\
\text { (TypeB) }\end{array}$ & $\begin{array}{l}\text { Red pine forest } \\
\text { (TypeB) }\end{array}$ & - & - & $\begin{array}{l}\text { Coniferous forest, } \\
\text { needles wide, } \\
\text { mixed forest }\end{array}$ & - & $\begin{array}{c}\text { Larch forest } \\
\text { (windbreak forest } \\
\text { etc.) }\end{array}$ & $\begin{array}{c}\text { Larch forest } \\
\text { (windbreak forest) }\end{array}$ & $\begin{array}{l}\text { Red pine forest, } \\
\text { spruce forest, } \\
\text { etc. }\end{array}$ & $\begin{array}{l}\text { Red pine forest, } \\
\text { cedar forest, etc. }\end{array}$ \\
\hline & $\mathrm{DBH}(\mathrm{cm})$ & $\begin{array}{c}36.8 \\
( \pm 11.3) \\
\end{array}$ & $\begin{array}{r}32.4 \\
( \pm 8.9)\end{array}$ & $\begin{array}{r}32.4 \\
( \pm 8.9) \\
\end{array}$ & - & - & - & - & $\begin{array}{c}20.1 \\
( \pm 4.6) \\
\end{array}$ & $\begin{array}{c}23.4 \\
( \pm 4.3) \\
\end{array}$ & $\begin{array}{c}19.9 \\
( \pm 4.4) \\
\end{array}$ & - \\
\hline & Height(m) & $\begin{array}{c}20 \\
( \pm 3.1) \\
\end{array}$ & $\begin{array}{c}18.9 \\
( \pm 2.7)\end{array}$ & $\begin{array}{c}18.9 \\
( \pm 2.7)\end{array}$ & - & - & - & - & & $\begin{array}{c}18.4 \\
( \pm 3.6)\end{array}$ & $\begin{array}{c}13.9 \\
( \pm 3.1)\end{array}$ & - \\
\hline & $\begin{array}{c}\text { Density } \\
\text { (stems/ha) }\end{array}$ & $\begin{array}{c}363 \\
( \pm 66.1) \\
\end{array}$ & $\begin{array}{c}525 \\
( \pm 135.8) \\
\end{array}$ & $\begin{array}{c}525 \\
( \pm 135.8) \\
\end{array}$ & - & $250 \sim 1500$ & - & $125 \sim 700$ & $\begin{array}{c}489.8 \\
( \pm 130.2) \\
\end{array}$ & $\begin{array}{c}523.5 \\
( \pm 171.0) \\
\end{array}$ & $\begin{array}{c}1018.8 \\
( \pm 282.0) \\
\end{array}$ & - \\
\hline \multicolumn{2}{|c|}{ Surrounding area } & & Forest, Cropland & & $\begin{array}{l}\text { Distribute Forest } \\
\text { and Cropland in } \\
\text { patch }\end{array}$ & $\begin{array}{l}\text { Distribute Forest } \\
\text { and Cropland in } \\
\text { patch }\end{array}$ & $\begin{array}{l}\text { tit Distributed } \\
\text { mosaic of forest } \\
\text { and cropland }\end{array}$ & \multicolumn{2}{|c|}{$\begin{array}{l}\text { Forest, cropland, Forest, cropland } \\
\text { Satoyama }\end{array}$} & Cropland & Cropland & $\begin{array}{l}\text { Elevation 10m to } \\
1130 \mathrm{~m} \text {, a low } \\
\text { mountain zone } \\
\end{array}$ \\
\hline & No. & 12 & 13 & 14 & 15 & 16 & 17 & 18 & 19 & 20 & 21 & 22 \\
\hline \multirow{2}{*}{\multicolumn{2}{|c|}{ References, etc. }} & 2006 & 2006 & 1998 & 2006 & 2007 & 1999 & 2001 & & 1996 & & 2008 \\
\hline & & Ueda et al. & Horie et al. & $\begin{array}{c}\text { Maebashi } \\
\text { Forestry } \\
\text { Administration }\end{array}$ & Ueda et al. & Uchida et al. & $\begin{array}{l}\text { Saitama Prefecture, } \\
\text { Northern goshawk, } \\
\text { etc. protection } \\
\text { guidelines } \\
\end{array}$ & Hasebe et al. & & Kosaka et al. & & $\begin{array}{c}\text { Foundation road } \\
\text { Institute for } \\
\text { Environmental } \\
\text { Studies } \\
\end{array}$ \\
\hline \multirow{2}{*}{\multicolumn{2}{|c|}{ Nesting area }} & \multicolumn{3}{|c|}{ Tochigi prefecture } & $\begin{array}{l}\text { Throughout } \\
\text { Nagano }\end{array}$ & \multicolumn{2}{|c|}{ Saitama prefecture } & $\begin{array}{l}\text { Throughout } \\
\text { Kumamoto }\end{array}$ & \multicolumn{4}{|c|}{ The whole of Japan } \\
\hline & & $\begin{array}{c}\text { Knuma city, } \\
\text { Utsunomiya city } \\
\text { - suty }\end{array}$ & Nasuno & togahara & Prefecture & $\begin{array}{l}\text { Hilly terrain of } \\
\text { the main area }\end{array}$ & $\begin{array}{c}\text { Throughout } \\
\text { Saitama }\end{array}$ & Prefecture & (1993) & 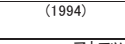 & (1995) & $(1989-2004)$ \\
\hline \multirow{4}{*}{$\begin{array}{l}\text { Nesting } \\
\text { tree }\end{array}$} & Tree type & $\begin{array}{l}\text { Pカマッ, スギ等 } \\
\text { Pinus densifiora, } \\
\text { Cryptomeria } \\
\text { japonica etc. }\end{array}$ & $\begin{array}{l}\text { アカマ゙ツ } \\
\text { Pinus densiffora }\end{array}$ & $\begin{array}{l}\text { Pカマ゙ } \\
\text { Pinus densiffora }\end{array}$ & $\begin{array}{l}\text { Pカマッ, モミ } \\
\text { Pinus densifora, } \\
\text { Abies firma }\end{array}$ & $\begin{array}{l}\text { Pカマ" } \\
\text { Pinus densiffora }\end{array}$ & $\begin{array}{l}\text { アガマッ, ス代等 } \\
\text { Pinus densifira, } \\
\text { Cryptomeria } \\
\text { japonica etc. }\end{array}$ & $\begin{array}{l}\text { アカマ゙ツ } \\
\text { Pinus densiflora }\end{array}$ & & $\begin{array}{l}\text { Pカフマ” } \\
\text { Pinus densiflora, Cryp }\end{array}$ & 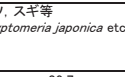 & \\
\hline & $\mathrm{DBH}(\mathrm{cm})$ & $\begin{array}{c}43.5 \\
( \pm 11.8) \\
\end{array}$ & $\begin{array}{l}34.8 \\
( \pm 1.2) \\
\end{array}$ & - & $\begin{array}{c}37 \\
( \pm 6.0) \\
\end{array}$ & $\begin{array}{c}30.6 \\
( \pm 7.2) \\
\end{array}$ & $\begin{array}{c}39.3 \\
(20.0-80.0)\end{array}$ & 60 & $\begin{array}{l}41.2 \\
( \pm 17.6) \\
\end{array}$ & $\begin{array}{c}40.8 \\
( \pm 17.9) \\
\end{array}$ & $\begin{array}{r}39.7 \\
( \pm 17.4) \\
( \pm 2\end{array}$ & $\begin{array}{c}40.3 \\
( \pm 1.0) \\
\end{array}$ \\
\hline & Height(m) & $\begin{array}{l}23.7 \\
( \pm 5.8)\end{array}$ & $\begin{array}{c}17.8 \\
( \pm 0.6)\end{array}$ & - & $\begin{array}{l}24.8 \\
( \pm 2.8)\end{array}$ & $\begin{array}{c}16.5 \\
( \pm 2.9)\end{array}$ & $\begin{array}{c}19.5 \\
(11.0-30.0)\end{array}$ & $\begin{array}{c}14.5 \\
( \pm 0.7)\end{array}$ & $\begin{array}{c}15.5 \\
( \pm 6.1)\end{array}$ & $\begin{array}{l}17.5 \\
( \pm 5.8)\end{array}$ & $\begin{array}{c}17.7 \\
( \pm 5.8)\end{array}$ & $\begin{array}{c}20.7 \\
( \pm 0.4)\end{array}$ \\
\hline & $\begin{array}{c}\text { Nest } \\
\text { height( } m)\end{array}$ & $\begin{array}{c}16.8 \\
( \pm 8.9) \\
\end{array}$ & $\begin{array}{c}12.7 \\
( \pm 0.5) \\
\end{array}$ & - & $\begin{array}{c}19.3 \\
( \pm 3.0) \\
\end{array}$ & $\begin{aligned} & 12.5 \\
&( \pm 2.6)\end{aligned}$ & $\begin{array}{c}14 \\
(8.0-23.0) \\
\end{array}$ & 7 & - & - & - & $\begin{array}{c}15 \\
( \pm 0.4) \\
\end{array}$ \\
\hline \multirow{4}{*}{$\begin{array}{l}\text { Nesting } \\
\text { forest }\end{array}$} & Forest type & $\begin{array}{l}\text { Cedar plantation, } \\
\text { coppice }\end{array}$ & $\begin{array}{l}\text { Red pine forest, } \\
\text { cedar forest etc. }\end{array}$ & Red pine forest & $\begin{array}{l}\text { Red pine forest, } \\
\text { fir forest }\end{array}$ & - & $\begin{array}{l}\text { Red pine forest, } \\
\text { cedar and } \\
\text { cypress forest }\end{array}$ & $\begin{array}{l}\text { 10th to 20th } \\
\text { grade Quercus } \\
\text { forest }\end{array}$ & - & - & - & - \\
\hline & $\mathrm{DBH}(\mathrm{cm})$ & - & 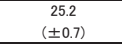 & 26.4 & - & - & - & - & - & - & - & $\begin{array}{c}33.7 \\
( \pm 3.2) \\
\end{array}$ \\
\hline & Height(m) & - & - & 17.1 & - & - & - & - & - & - & - & $\begin{array}{c}18.8 \\
( \pm 0.9) \\
\end{array}$ \\
\hline & $\begin{array}{c}\begin{array}{c}\text { Density } \\
\text { (stems/ha) }\end{array} \\
\end{array}$ & - & $\begin{array}{c}620.1 \\
( \pm 45.3) \\
(\end{array}$ & 1310 & - & - & - & - & - & - & - & $\begin{aligned} 619.8 \\
( \pm 79.6) \\
\end{aligned}$ \\
\hline \multicolumn{2}{|c|}{ Surrounding area } & Forest, cropland & Forest, cropland & Forest, cropland & $\begin{array}{l}\text { Forest, paddy } \\
\text { field }\end{array}$ & Cropland & Forest, cropland & $\begin{array}{l}\text { Forest, } \\
\text { cultivated land, } \\
\text { cutting and } \\
\text { reclamation area }\end{array}$ & - & - & - & - \\
\hline
\end{tabular}

表 9. 植生・土地被覆図の面積及び面積割合

Table 9. Area and ratio of area of vegetation and land cover map

\begin{tabular}{lrrrr}
\hline \multicolumn{1}{c}{ Area name } & Area (ha) & $\begin{array}{c}\text { Ratio of } \\
\text { area (\%) }\end{array}$ & Area (ha) $\begin{array}{c}\text { Ratio of } \\
\text { area (\%) }\end{array}$ \\
\hline \hline Pine forest & 679.74 & $24.04 \%$ & & \\
Cedar and cypress forest & 159.84 & $5.65 \%$ & 1691.59 & $59.82 \%$ \\
Broad-leaved forest & 852.01 & $30.13 \%$ & & \\
Low trees and bushes & 59.45 & $2.10 \%$ & & \\
Windbreak forest & 6.83 & $0.24 \%$ & & \\
Grassland & 507.38 & $17.94 \%$ & & \\
Cultivated land \& Paddy field & 332.83 & $11.77 \%$ & & \\
Open water & 25.82 & $0.91 \%$ & 1136.29 & \\
Road \& Parking area & 74.8 & $2.65 \%$ & & \\
Urban area \& Built up area & 76.72 & $2.71 \%$ & & \\
Bamboo grove & 46.88 & $1.66 \%$ & & \\
Wasteland & 5.58 & $0.20 \%$ & & \\
\hline
\end{tabular}

表 10．前橋営林局（1998）が示した採餌行動域の面積割合

Table 10. Recommended ratio for the foraging area for Accipiter gentilis (Maebashi Bureau of Forestry 1998)

\begin{tabular}{lll}
\hline Ratio of area & Type of Forest land cover & \multicolumn{1}{c}{ Note } \\
\hline \hline $50 \sim 60 \%$ & Mature forest & $\begin{array}{l}\text { Different growth stage forests } \\
\text { should form a mosaic pattern } \\
\text { throughout the area for foraging. }\end{array}$ \\
\hline $40 \sim 50 \%$ & $\begin{array}{l}\text { Openland, new afforestation } \\
\text { forest, yong forest, etc. }\end{array}$ & . \\
\hline
\end{tabular}


2003 年 A タイプと 2011 年 B タイプは, いずれも高 木層の林冠下部と亜高木層の林冠上部の間に空間が 広がっていることが確認できた.また, 2011 年は A, B, $\mathrm{E}$ タイプで垂直方向の飛翔空間が広がっていた（図 11).

\section{（3）植生に関する小括}

2006 ～ 2010 年に行われた施業（間伐，除伐，マツ 枯れ対策）の結果，立木密度の低下により，全林齢 タイプでアカマツが成長し, 営巣可能な大径高木が 増加していた。また, 立木密度が低い上, 垂直方向 の空間が広いなど, 林内の飛翔空間が確保されてい た. そのため, オオタカの営巣環境の改善という観 点から施業は適切であったと考えられる。

\section{2. 鳥類}

\section{（1）オオタカの採慨環境}

オオタカを保全するためには，その餌動物を明ら かにし，才オタカが利用可能な食物の量を維持する 必要がある (Reynolds et al. 1992). 事例研究地におけ る好適餌種の出現個体数の合計值上位 3 種はヒヨド リ, キジバト, イカルであり, ヒヨドリが最も多かっ た（図 13,14）ため, これらがオオタカの主要な餌 と考えられる. 先行研究でもヒヨドリ, キジバトが 主要な餌となっている可能性が示唆されている（関 東森林管理局 2008).

森林地帯のオオタカは林内でも採餌する（Widen 1989）ため, 事例研究地の林内における好適餌種の出 現個体数に着目した. $2010 \cdot 2011$ 年に営巣林であっ た Bタイプは, $2003 〜 2004$ 年に比較して, $2011 〜$ 2012 年の好適餌種の出現個体数が減少していた(表 7, 図 12)。この原因として, 低木層と草本層の植被率の 変化が考えられる. 先行研究により森林内部の植生 が鳥類の生息状況に関係することが明らかとなって いる（由井 1988）。他地域のオオタカ生息地では, ヒ ヨドリ・イカル・カケスは低木層の中〜密な林に多く, キジバト・アオバトは, 低木層の中〜密, 草本層は 無いか疎な林の方が多いことが明らかとなっている (関東森林管理局 2008). B タイプでは $2011 ２ 012$ 年の方が低木層の植被率は低くなっており, 草本層 の植被率は高くなっていた（表 5)。低木層の植被率 が低下した原因は, 除伐や踏み入りの影響, 草本層 の植被率が増加した原因は, 間伐及び除伐により立 木密度が低下したことで林内の光環境が改善され, 草本層の生育が旺盛になったことが考えられる。こ
のことから，施業が必ずしも好適餌種にとって好適 な生息環境の形成に寄与したとは言えない.

しかしながら, 全調査地点の出現個体数の平均值 は2011〜2012 年の方が多く, クロス検定の結果, $2003 \sim 2004$ 年と $2011 ２ 012$ 年の好適餌種とその他 の出現個体数については, 有意な差がみられなかっ た. その理由として, 全ての林齢タイプにおいて, 好適餌種の餌となるサクラ類やミズキ等の樹木が亜 高木層及び低木層の優占種として生育していたこと から, 鳥類の生息を助けている可能性が考えられる. また, 営巣林の周辺には, ヒヨドリが良く利用する 林縁 (由井 1988 ; 黒沢ほか 1999) や, 耕作地, 草地 等の多様な環境が存在するため, 全体として出現個 体数にほとんど変化が無かったと考えられる．また， 好適餌種の季節変化をみると, 2003 ～ 2004 年, 2011 〜 2012 年とも好適餌種の出現個体数が最も多かった のは春季〜初夏であり（図 13，14），2011～2012 年 はクロス検定により有意差がみられた。この時期は オオタカの抱卵期〜育雛期にあたる（環境省自然環 境局野生生物課 2012). 餌重量は㱀の日齢とともに増 加する（Rogers et al. 2006）ため, この時期に出現個 体数が多い, 寸なわち餌種バイオマス量が多いこと は, オオタカの健全な育雛にとって良い環境である と考えられる.

次に, オオタカ推定行動圈における植生・土地被 覆と採餌可能域の広がりについて考察する. 前橋営 林局（1998）は，アメリカの「オオタカの保護管理の ための森林管理推奨方策」において提案されている 採食行動域の構造（Reynolds et al. 1992）を参考にし, 適切な採餌環境の構造を推測している（表 10).これ を参考にして, 事例研究地のオオタカの推定行動圏 内における植生・土地被覆の面積をみると, 森林（ア カマツ林, スギ・ヒノキ植林, 広葉樹林) 1691.59 ha $(59.82 \%)$, その他（低木林, 草地, 耕作地, 開放水面, 市街地 他) 1136.29 ha (40.18\%) であり, 表 10 の 壮齢林 $(50 \sim 60 \%)$, その他: 伐開跡地, 新植地, 若 齢林など $(40 〜 50 \%)$ の面積割合を満たしていた。 そのため, 事例研究地のオオタカの推定行動圈内に は適切な採餌可能域が広がっていると考えられる。

また, 植生・土地被覆の分布状況は, アカマツ林, スギ・ヒノキ植林, 広葉樹林などの森林, 重要な採 餌環境である草地, 耕作地 (畑, 水田) は推定行動 圈内全域に分布していた。低木林, 防風林, 竹林, 開放水面, 裸地は少ない面積だが全域に飛び石状に 散らばって分布していた. オオタカの推定行動圈内 
に多様な環境が分散して分布していることは，採餌 環境として望ましい環境である（前橋営林局 1998 ; 環境省自然環境局野生生物課 2012).

\section{（2）鳥類の種多様性と植生の関係}

$2011 \sim 2012$ 年の鳥類の確認種数は, $2003 \sim 2004$ 年よりも少なかった（表 6). $2011 〜 2012$ 年の H’は $2003 \sim 2004$ 年と比べ, 通年は低く, 繁殖期は高かった。 母平均の差の検定より, 施業前後の $\mathrm{H}^{\prime}$ に有意な差は みられなかった。 そのため, 事例研究地における鳥 類群集の多様性は, 施業前後で大きく変化しなかっ たと考えられる.

森林内について, 事例研究地における繁殖期の鳥 類の H’平均值（森林内 : $2003 \sim 2004$ 年 3.517, 2011 〜 2012 年 3.600 ) を, 全国 190 箇所余の H’ (由井 1988）と比較すると, 暖帯・暖温帯壮齢単純人工林 2.893, 暖帯・暖温帯壮齢人工林（広葉樹混交） 3.106, 泠温帯壮齢単純人工林 3.138 , 冷温帯壮齢人工林 (広 葉樹混交） 3.729 など他の人工林と比べても高いか同 等の多様度の高さを示すことがわかった。広葉樹林 と比較すると, ブナ林 3.247 , ミズナラ林 3.666 , クヌ ギ・コナラ林 3.125 (由井 1988), 森吉山ブナ林の平 均は 3.44 (鈴木 2000）であり, 広葉樹林と比べても 高いか同等の多様度を示していた。鳥類群集は, 成 熟した背の高い天然林や広葉樹を交えた壮齢人工林 で時に天然林より豊かになる（由井 1988 ; 樋口 1996） ことや, 森林の各階層がよく発達している森林で多 様になること（MacArthur \& MacArthur 1961）が指摘 されている. 事例研究地のアカマツ林は人工壮齢林 であり, 各階層に広葉樹が茂っているため, 鳥類群 集の多様性が豊かな林となったと考えられる。また, 事例研究地における植生と鳥類の種多様性の関係に ついては, GLMにより, FLD と鳥類の H’ に有意な 相関はみられなかった。 これは, 施業により各林齢 タイプの植生に大きな差が生じず, 均質な林内環境 が維持されたため, 鳥類群集の多様性にほとんど変 化がみられなかったと考えられる。

森林外についても森林内の H’ と同等に多様性が高 かった. 里地里山は多様な動植物の生息地となって いる（村上 2018）ことから, 事例研究地とその周辺 に里地里山として多様な環境が広がっていることが, 多様性が高い一因であると考えられる.

\section{（3）鳥類に関する小括}

全調査地点の鳥類の出現個体数と $\mathrm{H}^{\prime}$ より, 施業に
よる鳥類群集への大きな影響は生じていないと考え られる.また, $\mathrm{H}^{\prime}$ は, 繁殖期に高くなっており, 先 行研究の人工林及び広葉樹林に比べても同等か高 かった. しかし, 好適餌種の出現個体数が B タイプ で減少していたことから, 鳥類群集の今後の動向に 留意することが望ましい.

\section{3. オオタカの生息地と用材林という 2 側面からみた マツ林に対する森林管理の意義}

種としてのオオタカは, 主に北半球の環北極地域 に広く分布している. 日本国内の分布については, 上野（2015）が全国スケール（東北以南）でのオオタ カの営巣適地の予測結果を算出している。これをみ ると, 本州, 四国, 九州に広く営巣適地が広がって おり, 特に関東地方で生息ポテンシャルが高い. 事 例研究地の立地する鳥取県の生息ポテンシャルは 0.5 〜 0.8 と全国的にみて高い值が算出されている.

営巣木の樹種としては海外, 国内にかかわらず針 葉樹をはじめとした様々な樹種を利用している（尾 崎・遠藤 2008). 日本国内をみると, 営巣木の樹種は, アカマツ, スギ, モミ, カラマツの順に多い（尾崎・ 遠藤 2008). 日本におけるマツ林の大半はアカマツ二 次林であり, 冷温帯の青森県から暖温帯の鹿児島県 まで広く分布している（福嶋・岩瀬 2005）。江戸期に

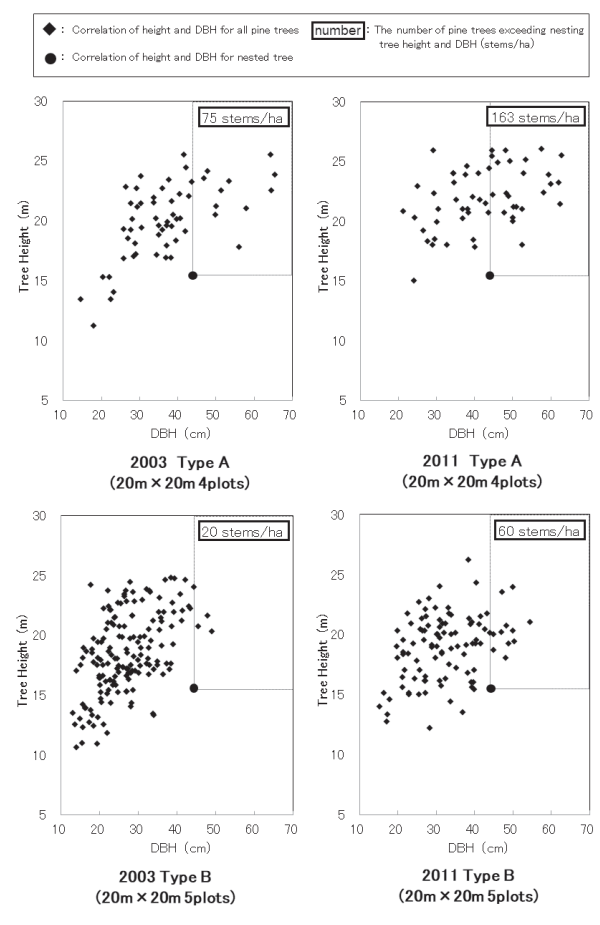

図 15. アカマツの胸高直径一樹高相関図 Figure 15. Pine tree diameter at breast height (DBH) and a height correlation diagram 
かつて草山が広がっていた里山には，近代にはその 多くはコナラやアカマツが優占する二次林に移行し た（田村 1994 ; 小椋 1996）。これに加え, アカマツ人 工林は戦後の昭和 30 年頃から全国に造林された（大 住 私信). 里山に広がるアカマツ林の分布と同様に才 オタカの分布も全国的に里山に多く，これらの主な 分布域は重なっていると考えられる. つまり, 多く のオオタカは, 日本全国の里地里山に広がる二次林 としてのアカマツ林や戦後造成されたアカマツ人工 林に分布していると考えられる.

アカマツは伝統的な和風建築の構造材, 特に梁材 として用いられるが，事例研究地を含む大山山麗は 大山マツの産地として有名な地域であり, 高級建築 用材として高い評価を受けて需要が高かった（鳥取 県 1962 ; 大山町誌編集委員会 2010). そのため, 1924 （大正 13）年頃からアカマツ人工林が造成・管理され, 大径高木が育成されてきた（大山町誌編集委員会 2010). そのような経緯が, オオタカに営巣林として 選択される林内空間のある大径高木のマツ林を作り 出したといえる. そして, 間伐の結果, 用材林の育 成という側面から考えても $450 \sim 500 \mathrm{~m}^{3} / \mathrm{ha}$ 前後の収 量が得られる大径高木を育成できる立木密度となっ ており, 人工林の密度管理の観点からも適切である と考えられる，つまり，用材林として大径高木を育 成するための管理が，オオタカの生息地保全にも寄 与しており, オオタカの生息地と用材林という2 側 面をもった森林が成立したと考えられる.

しかし，1955（昭和 30）年頃から造成されたアカ マツ人工林は, 板材や梁材としてのアカマツ材の需 要減少に伴い, 供給量が減少し, 現在では管理が実 施されていない地域がほとんどである（大住 私信）。 また，オオタカの生息環境をより適切に管理するた めに, 営巣林の施業を実施した例はほとんどない. 二次林としての性質をもつアカマツ林は, そのまま 放置していると，いずれはコナラ等を主体としたナ ラ林, またはカシ類の優占する森林へと遷移が進む (中山ほか 2005)。また, 二次林・人工林いずれのア カマツ林も性質は同様であり, オオタカの生息地保 全の観点からみても, 間伐, 除伐などの森林管理を 行うことは重要だと考えられる.

\section{4. 今後の森林管理への提案}

以上の考察をもとに, 今後の短期的な森林管理計 画を提案する. B タイプは営巣可能な林分として現状 を維持し，そのほかの林齢タイプ，特に垂直空間が
ほとんどない又は全くない C, D タイプは除伐を行う ことで，林内の飛翔空間を改善することが望ましい. 加えて, 松くい虫被害木が継続して確認されてい るため, 引き続き松枯れ対策が必要である.オオタ カへの影響や生態系保全を考慮すれば, 薬剤散布等 の方法は用いず，枯死木の除伐及び燻蒸処理が望ま しい。また，今後さらに被害が増大した場合は，ス ギ (Cryptomeria japonica), モミ (Abies firma) 等の代 替樹種もあわせて植林することも検討の余地がある.

鳥類群集の多様性を維持するためには, 林内の各 階層に広葉樹が混交する壮齢人工林を維持すること が重要だと考えられる。また，好適餌種の生息環境 を考えると, 低木層や草本層の植被率の改善や, 餌 となる花や実をつける樹木を残すなどの配慮が望ま しい. 亜高木層はオオタカの飛翔空間であるため, あまりに茂りすぎるとオオタカの飛翔を妨げる恐れ がある、そのため, 除伐は行いながら, 鳥類群集の 動向についてモニタリング調査も行うことが望まし い.

\section{結 論}

オオタカは, 主として里地里山を象徵する生態系 上位種である. 里地里山は農地と森林がモザイク状 に分布した景観を成しており，このモザイク景観が オオタカの採餌環境として利用されていた。 また, 里地里山の森林であるアカマツ林は, 営巣環境とし て利用されていた. オオタカの営巣環境として重要 な要素である(1)営巣木として利用できる大径高木の 育成, (2)林内の飛翔空間の確保の 2 点は, 用材林と してのアカマツ林の管理としても適切であり, オオ タカの生息地保全と用材林育成は両立を図ることが 出来ると明らかになった。

\section{謝 辞}

特定非営利活動法人日本野鳥の会鳥取県支部の皆 様には, 鳥類調查にご協力いただいた。 また, 鳥取 県西部総合事務所生活環境局生活安全課の皆様には, 鳥取県立大山オオタカの森における間伐等の施業履 歴及び調査データの使用承認をいただいた。鳥取大 学の大住克博名誉教授には, アカマツ人工林拡大の 社会的背景についてご教示いただいた. 記して以上 の方々に感謝申し上げたい. 


\section{引用文献}

安藤貴. 1982. 実践林業大学 XXV 林分の密度管理. $126 p p$. 農林出版株式会社. 東京.

Beier, P. and Drennan, J. E. 1997. Forest structure and prey abundance in foraging areas of Northern Goshawks. Ecological Applications 7: 564-571.

Boal, C. W., Andersen, D. E. and Kennedy, P. L. 2005. Foraging and nesting habitat of breeding male Northern Goshawks in the Laurentian mixed forest province, Minnesota. Journal of Wildlife Management 69: 15161527.

Boal, C. W., Andersen, D. E., Kennedy, P. L. and Roberson, A. M. 2006. Northern Goshawk ecology in the western Great Lakes region. Studies in Avian Biology 31:126-134.

Bosakowski, T., McCullough, B., Lapsansky, F. J. and Vaughn, M. E. 1999. Northern Goshawks nesting on a private industrial forest in western Washington. Journal of Raptor Research 33: 240-244.

Braun-Blanquet, J. 1964. Pflanzensoziologie. Grundzügeder Vegetationskunde. 865pp. 3. Aufl. Wien, New York. 鈴木時夫訳. 1971. 植物社会学 I, II, 朝倉書店。東京.

Burt, W. H. 1943. Territoriality and home range concepts as applied to mammals. Journal of Mammalogy 24: 346-352.

大山町誌編さん委員会. 1980. 大山町誌. $1284 \mathrm{pp}$. 大山町長 入江正雄. 鳥取.

大山町誌編集委員会. 2010. 続大山町誌. 900pp. 大 山町. 鳥取.

Daw, S. K,, DeStefano, S. and Steidl, R. J. 1998. Does survey method bias the description of Northern Goshawk nest-site strugture? Journal of Wildlife Management 62: 1379-1384.

DeStefano, S. 1998. Determining the status of the Northern Goshawks in the West: is our conceptual model correct? Journal of Reptor Research 32: 342-348. 財団法人 道路環境研究所. 2008. オオタカの人工代 替巣設置に関する手引き（案）. $39 \mathrm{pp}$. 財団法人 道路環境研究所. 東京.

遠藤孝一・小金沢正昭．1989．林業から見たオオ夕 力営巣地の保護管理. 日本鳥学会誌 37. 185.

Finn, S. P., Varland, D. E. and Marzluff, J. M. 2002. Does Northern Goshawk breeding occupancy vary with nest- stand characteristics on the Olympic Peninsula, Washington? Journal of Raptor Research 36: 265-279. 福嶋司・岩瀬徹. 2005. 図説日本の植生. 153pp. 朝倉書店. 東京.

樋口広芳. 森林と鳥の多様性. 1996. 森林科学 16(0): 34-38.

平井克亥 - 瀧本育克 - 柳川久. 2008. 北海道十勝地 方におけるオオタカとハイタカの営巣環境とその 保全. 第 7 回「野生生物と交通」研究発表会 講演 論文集. 51-56.

堀江玲子 - 遠藤孝一 - 野中 純 - 船津丸弘樹 - 小金 澤正昭. 2006. 栃木県那須野ヶ原におけるオオタ 力の営巣環境選択. 日本鳥学会誌 55(2): 41-47.

堀江玲子. 遠藤孝一 - 山浦悠一 - 尾崎研一. 2008. 杤木県におけるオオタカ雄成鳥の行動圏内の環境 選択. 日本鳥学会誌 57(2): 108-121.

環境庁自然保護局野生生物課. 1996. 猛禽類保護の進 め方: 特にイヌワシ, クマタカ, オオタカについて. $87 \mathrm{pp}$. 公益財団法人日本鳥類保護連盟. 東京.

環境省自然環境局野生生物課. 2012. 猛禽類保護の 進め方（改訂版）: 特にイヌワシ, クマタカ, 才 オタカについて. 88pp. 環境省自然環境局野生生 物課. 東京.

関東森林管理局. 2008. オオタカの営巣地における 森林施業 2: 生息環境の改善を目指して. 169pp. 一般社団法人日本森林技術協会. 東京.

吉良竜夫. 1949. 日本の森林帯: 林業解説シリーズ 17. $42 \mathrm{pp}$. 日本林業技術協会. 東京.

小俣信一郎. 1999. 37 の事例から見たオオタカの営 宩環境. PREC STUDY REPORT Vol.05: 40-41.

近藤芳五郎. 1995. 山陰のマツ: 戦後 50 年をふりか えって. 181pp. 近藤芳五郎. 鳥取.

黒沢令子・Robert A. Askins. 1999. 林縁と林内の鳥 類群集の違い：日本に林内種はいるか? . 山科鳥 類研究所研究報告 31(2): 63-79.

MacArthur, R. H. and MacArthur, J. W. 1961. On Bird Species Diversity. Ecology 42: 594-598.

前橋営林局. 1998. オオタカの営巣地における森林 施業: 生息環境の管理と間伐等における対応. 142 pp. 一般社団法人日本林業技術協会. 東京.

松江正彦・百瀬 浩 - 植田睦之・藤原宣夫. 2006. オオタカ (Accipiter gentilis) の営巣密度に影響す る環境要因. 平成 18 年度日本造園学会全国大会研 究発表論文集 24. ランドスケープ研究 69(5): 513518. 
宮脇昭 - 奥田重俊 - 藤原一絵 - 鈴木邦雄. 1979. 中 国地方の潜在自然植生図. 3pp. 環境科学特別研究 総合班. 東京.

村井英紀 - 樋口広芳. 1988. 森林性鳥類の多様性に 影響する諸要因. Strix 7: 83-100.

村上拓彦．2018．農地を囲む土地利用の空間分布パ ターンと里地里山の生物多様性保全. 日本リモー トセンシング学会誌 38(3): 266-268.

農林水産技術会議事務局. 2003. アンブレラ種であ るオオタカを指標とした生物多様性モニタリング 手法の開発に関する研究. 環境保全研究成果集 415. 29. 1-29. 17.

小椋純一. 1996. 植生からよむ日本人のくらし一明 治期を中心に. pp.246. 雄山閣出版. 東京.

尾崎研一 - 遠藤孝一. 2008. オオタカの生態と保全. $147 \mathrm{pp}$. 一般社団法人日本森林技術協会. 東京.

Pielou, E. C. 1969. An Introduction to Mathmatical Ecology. Wiley-Interscience.

Recher, H. F. 1969. Bird species diversity and habitat diversity in Australia and North America. American Naturalist 103: 75-80.

Reynolds, R. T., Graham, R. T., Reiser, M. H., Bassett, R. T., Kennedy, P. L., Boyce, D. A., Goodwin, G., Smith, R. and Fisher, E. L. 1992. Management Recommendations for the Northern Goshawk in the Southwestern United States. RSDA Forest Service. General Technical Report RM. 217.

林野庁. 2017. 平成 29 年版森林 - 林業白書. $314 p p$. 全国林業改良普及協会. 日本.

Rogers, A. S., DeStefano, S. and Ingraldi, M. F. 2006. Diet, prey delivery rates and prey biomass of Northern Goshawks in east-central Arizona. Studies in Avian Biology 31: 260-273.

佐藤義明. 1971. 優しい測樹の実務. 214pp. 農業図 書. 東京.

四手井鋼英 ·佐野宗一. 1973. 松と人生. 297pp. 明 玄書房. 東京.

Squires, J. R. and Kennedy, P. L. 2006. Northern Goshawk ecology: an assessment of current knowledge and information needs for conservation and management. Studies in Avian Biology 31: 8-62.

鈴木祥悟. 2000. 森吉山ブナ林の繁殖鳥類群集. 東 北森林科学会誌 5(1): 27-30.

鈴木貴志. 1999. 北海道十勝平野におけるオオタカ Accipiter gentilisno の営巣環境. 日本鳥学会誌
48(2): 135-144.

田村説三. 1994. まぐさ場（秝場）の植生とまぐさ 場期限の二次林. 埼玉県自然史博物館研究報告 12 : 73-82.

鳥取県. 1962. 鳥取県の林業 1962 年版. 19pp. 鳥取 県. 鳥取.

鳥取県農林部農業指導課. 1974. 大山山ろく開発地 域土地分類基本調査: 赤崎 - 大山. 50pp. 鳥取県 農林部農業指導課. 鳥取.

鳥取県生活環境部公園自然課. 2012. レッドデータ ブックとっとり改訂版: 鳥取県の絶滅のおそれの ある野生動植物. $337 \mathrm{pp}$. 鳥取県生活環境部公園自 然課 (鳥取県生物学会編). 鳥取.

内田博 - 高柳茂 - 鈴木伸 - 渡辺孝雄 - 石松康幸 - 田 中功 - 青山信 - 中村博文 - 納見正明 - 中嶋英明 . 桜井正純. 2007. 埼玉県中央部の丘陵地帯での才 オタカAccipiter gentilis の生息状況と営巣特性. 日 本鳥学会誌 56(2): 131-140.

植田睦之 - 百瀬浩 - 山田泰広 - 田中啓太 - 松江正彦. 2006. オオタカの幼鳥の分散過程と環境利用. Bird Research 2(0): A1-A10.

上野裕介・栗原正夫. 2015. 広域スケールでのオオ タ力の生息適地予測の有効性と空間的汎用性 - 地 域性の課題. ランドスケープ研究 78(5): 647-650.

Widen, P. 1989. The hunting habitats of Coshawks Accipiter gentilis in boreal forests of central Sweden. Ibis 131: 205-213.

山中勤 - 松尾大悟 - 矢野翠 - 角張順一 - 飯田真一 - 涌 井久司・清水亮介 - 田中正. 2005. 遷移過程のアカ マツ二次林における植物種間の根系分布の差異. 筑 波大学陸域環境研究センター報告 No.6: 39-44.

由井正敏. 1974. 繁殖期における小鳥類の生息数調 查法に関する研究. 森林総合研究所林業試験場研 究報告 264: 13-84.

由井正敏. 1988. 森に棲む野鳥の生態学. 237pp. 創 文. 東京.

由井正敏・鈴木祥悟 - 青山一郎. 1989. 森林原野性 鳥類のラインセンサス法の研究 IX スポットセン サス法との比較. 山階鳥研報 21: 208-223. 